\title{
The ability to get everywhere: dispersal modes of free-living, aquatic nematodes
}

\author{
Christoph Ptatscheck (D) Walter Traunspurger
}

Received: 30 January 2020/Revised: 30 July 2020/Accepted: 1 August 2020/Published online: 11 August 2020

(C) The Author(s) 2020

\begin{abstract}
Nematodes colonize almost all aquatic habitats worldwide. Despite their small size, restricted locomotion and lack of pelagic larvae, they can reach even isolated habitats within a short time. In this review, we examine the underlying dispersal modes, considering their active movement in substrates and water, their drift by water and wind, rafting, zoochory as well as human-mediated vectors. These modes are limited by morphology and habitat structure, ecological factors and especially by hydrodynamics. Active dispersal is effective over short distances, but with increasing water-flow velocity, passive dispersal modes, which enable long-range transfer, become important. In fact, the transport of nematodes over thousands of kilometers via ship water tanks and by hitchhiking on sea turtles has been documented. Overland dispersal vectors include wind and birds whereas rafting enables an aggregated distribution because food is available, and reproduction is possible onboard the rafts. The diversity of possible dispersal modes is high and offers a reasonably chance for gravid females or groups of nematodes to be transferred even to remote environments. Their immigration is continuous, and supported by their rapid,
\end{abstract}

Handling Editor: Diego Fontaneto

C. Ptatscheck $(\bowtie) \cdot$ W. Traunspurger

Animal Ecology, University of Bielefeld, Konsequenz 45,

33615 Bielefeld, Germany

e-mail: christoph.ptatscheck@uni-bielefeld.de parthenogenetic reproduction, nematodes are effective pioneers with the ability to (re)colonize new or disturbed habitats or rebalance already existing communities.

Keywords Meiofauna paradox $\cdot$ Rafting ·

Zoochory $\cdot$ Drifting $\cdot$ Wind dispersal $\cdot$ Locomotion

\section{Introduction}

Nematodes are the most abundant metazoans in the biosphere and colonize nearly all aquatic and semiaquatic habitats worldwide. They can be found in permanent lotic and lentic surface waters, such as lakes and streams, and in the seabed. They have also been collected from high-altitude lakes (up to 5,600 m above sea level) (Andrássy, 1978; Tsalolikhin, 2014), from deep-sea regions (down to $11,000 \mathrm{~m}$ below sea level) (Bik et al., 2010; Leduc \& Rowden, 2018) and from caves and groundwater (Muschiol et al., 2015). In addition to these large-scale and permanent habitats, nematodes inhabit small, isolated and temporal environments, such as heat outlets or the volcanos of isolated islands (Muschiol \& Traunspurger, 2009; Portnova, 2009; Schabetsberger et al., 2009; Portnova et al., 2011; Schabetsberger et al., 2013), ephemeral ponds with no connection to other waters or created by melt water or subject to sporadic desiccation and 
surrounded by desert or ice (Suren, 1990; Pinder et al., 2000; Chan et al., 2005), as well as water collections in plant components (phytotelmata) (Kitching, 2000; Ptatscheck et al., 2015a; Robaina et al., 2015; Zotz \& Traunspurger, 2016).

Within these marine and freshwater habitats, nematodes can occur in considerable abundances, reaching densities of millions of individuals per square meter (Traunspurger, 2000; Michiels \& Traunspurger, 2005a; van Gaever et al., 2006; Schroeder et al., 2012; Traunspurger et al., 2012) and representing numerous species. For example, Beier \& Traunspurger (2003a, b , c) identified up to 113 nematode species in $\sim 100-\mathrm{cm}^{3}$ sediment samples $\left(26-\mathrm{cm}^{2}\right.$ sediment area) obtained from 2 streams during a 1-year period and Traunspurger (1996a, b) collected 116 species from a sediment sample of the same size from Lake Königssee. As an essential trophic link between the microbenthos (e.g., bacteria or rotifers) and larger organisms (macroinvertebrates or even juvenile fish), nematodes are crucial to nutrient cycling and energy flow in benthic environments.

A consideration of marine and freshwater nematodes on a global scale shows specific and non-random distribution patterns for many species (Artois et al., 2011; Moens et al., 2013; Zullini, 2014) whereas others were found to be ubiquitous. In their study of 18 nematode species from the Galapagos Islands, Abebe $\&$ Coomans (1995) showed that 10 were cosmopolitan, 6 were at least common in the southern hemisphere and the remaining 2 were newly described species. For example, Rhabdolaimus terrestris de Man, 1880 was collected from the Galapagos Islands but also inhabits bromeliad phytotelmata in Panama as well as European, Ethiopian and Himalayan lakes and Vietnamese streams (Traunspurger, 1995; Gusakov et al., 2011; Ristau \& Traunspurger, 2011; Schroeder et al., 2012; Tsalolikhin, 2014; Zotz \& Traunspurger, 2016). Genetic studies have provided evidence of gene flow between metacommunities separated by hundreds of kilometers and therefore of the possible dispersal range of nematodes (Bik et al., 2010; Apolônio Silva de Oliveira et al., 2017; de Groote et al., 2017). However, it is generally assumed that gene flow is mostly limited to distances $<100 \mathrm{~km}$ (Derycke et al., 2008, 2013; Hauquier et al., 2017). Cerca et al. (2018) showed in their review that, based on molecular investigations, even amphi-oceanic distribution of marine meiofauna taxa seldom occurs.
At local and habitat-based scales, the high distribution potential and importance of nematodes as pioneer organisms become obvious. Studies of artificial water-filled tree holes demonstrated their colonization by rotifers and especially by nematodes within a few days, despite the clear delimitation of these small island-like habitats and their isolation from other aquatic sources (Ptatscheck \& Traunspurger, 2014; Ptatscheck et al., 2015a). Similarly, the rapid immigration of nematodes and other meiobenthic taxa, including rotifers and microcrustaceans, within a single tidal cycle or a few days was described in studies on the colonization of azoic substrate patches in tidal areas, lakes and streams (Boulton et al., 1991; Peters et al., 2007; Boström et al., 2010). However, in other studies from freshwater and marine environments (Chandler \& Fleeger, 1983; Duft et al., 2002; Guilini et al., 2011; Zhou et al., 2015), even after weeks there was no complete adaptation of the species composition in the defaunated substrate or from the surrounding source habitats. Investigations on the colonization of ice after iceberg scouring and ice shelf collapses by meiofauna showed that nematodes, next to ostracods and copepods, are among the pioneer organisms, but the recovery process is slow (up to years) (Lee et al., 2001a, b; Hauquier et al., 2016). All those studies well demonstrated that dispersal is a key factor in understanding the structuring of nematode populations.

In addition to survivability, fecundity and sexual maturity, the dispersal potential of an organism is a crucial feature of its life history and sustained existence (Bonte \& Dahirel, 2017). Dispersal describes all movements of an individual or a propagule that lead to a spatial gene flow (Ronce, 2007). It can be distinguished in three successive phases: (1) emigration from the source habitat, (2) active or passive transfer to another habitat and (3) the final immigration (Bowler \& Benton, 2005; Bonte et al., 2012). The actual translocation (emigration and transfer) is often considered separately from the subsequent establishment processes comprising immigration (e.g., Nathan, 2001; Hessen et al., 2019). Dispersal enables individuals to avoid adverse living conditions (e.g., competition or predation) but also to recolonize habitats after catastrophic events or stabilize and expand the diversity of an existing community (Valanko et al., 2015). At the same time, high levels of interchange, for example between connected ponds 
(Akasaka \& Takamura, 2012), can lead to the homogenization of communities, a decrease in $\beta$ diversity or the dominance of a single, competitive taxon (Leibold et al., 2004; Matthiessen et al., 2010). The intensity of dispersal is thus a decisive factor in defining the diversity and stability of communities (Leibold et al., 2004; Cadotte, 2006; Howeth \& Leibold, 2010; Matthiessen et al., 2010; Carrara et al., 2012; Valanko et al., 2015).

Dispersal also ultimately affects the distribution and composition of benthic invertebrates (Grönroos et al., 2013; Kärnä et al., 2015; Tonkin et al., 2018; Tornero et al., 2018; Gansfort \& Traunspurger, 2019). However, these organisms are inhabitants of aquatic islands that are often not directly connected to similar habitats but are instead surrounded by a "dry ocean" (Incagnone et al., 2015). Furthermore, meiobenthic organisms such as nematodes are usually not associated with rapid movement and do not have pelagic larvae, such that dispersal within a habitat is unlikely. Thus, in referring to this so-called meiofauna paradox, Giere (2009) rightly asked: How can we explain a wide distribution of animals with almost no dispersive capacity? In this context, Cerca et al. (2018) already pointed out that the dispersal potential of meiobenthic organisms has been considerably underestimated in the past and the meiofauna paradox is rather to be regarded as a paradigm.

In this review, we consider the dispersal of freeliving nematodes from permanent freshwater and marine habitats, although some of the discussed dispersal modes, such as wind drift and transport on/ in larger animals, are also relevant for terrestrial species. However, due to their sometimes very (species-) specific dispersal, parasitic taxa were excluded. In focusing on the translocation (emigration and transfer) aspect of dispersal, we specifically asked: By what pathways can nematodes reach a given habitat? What are the triggers and influencing factors that determine nematode dispersal? How relevant are these modes for long-range dispersal?

A major difficulty in compiling this review was the comparability of the analyzed datasets since the included studies sometimes employed very different methodologies. Notably, the mesh sizes of the sieves used to extract the organisms of interest ranged from 1.2 to $>250 \mu \mathrm{m}$. In the study of Boulton et al. (1991), a mesh size of $63 \mu \mathrm{m}$ did not hinder nematode entry into the investigated enclosures. Recent studies showed that even a mesh size of $35 \mu \mathrm{m}$ does not result in the retention of all nematodes from a suspension (Ptatscheck et al., 2015b; KreuzingerJanik et al., 2018). Consequently, nematode abundance and diversity are often underestimated. In addition, many studies included in this review were primarily designed to investigate larger organisms, with nematodes collected accidentally and thus mentioned only incidentally. Therefore, to avoid misinterpretations, we generally refrain from detailed comparisons of the nematode densities determined in different studies and habitats.

The majority of studies on nematode dispersal have been carried out in marine environments, with an emphasis on water drift vs. active crawling/swimming. Reviews of the single dispersal modes of marine meiofauna (benthic invertebrates retained on a net with a mesh size of $44 \mu \mathrm{m}$ ); Giere (2009) can be found in Palmer (1988a), Armonies (1994) and Thiel \& Gutow (2004b) whereas our review provides the first detailed descriptions of all relevant dispersal modes detected in both marine and freshwater nematodes, i.e., (1) active dispersal within a water body (swimming and crawling), (2) passive dispersal by water drift, (3) rafting on floating items, (4) hitchhiking in/on animals (endozoochory and epizoochory), (5) wind drift and (6) anthropogenic vectors (Fig. 1).

\section{Traits relevant for dispersal}

\section{Locomotion}

The alternating contractions of the dorsal and ventral longitudinal muscles of nematodes are solely responsible for their active locomotion. The resulting undulatory movement, in which backward pressure is exerted against different forms of external resistance, pushes the nematode body forwards along the substrate (Gray \& Lissmann, 1964; Wallace, 1968). The form and frequency of these contractions and thus the nematode's progress depend on the surrounding medium. Due to its multilayer cuticula, the nematode body is less compressible such that the pore size of the sediment is an important parameter determining the speed of nematode movement. Larger nematodes move faster through the sediment than smaller ones, but the maximum speed is reached when particle diameters are three times smaller than the body length 


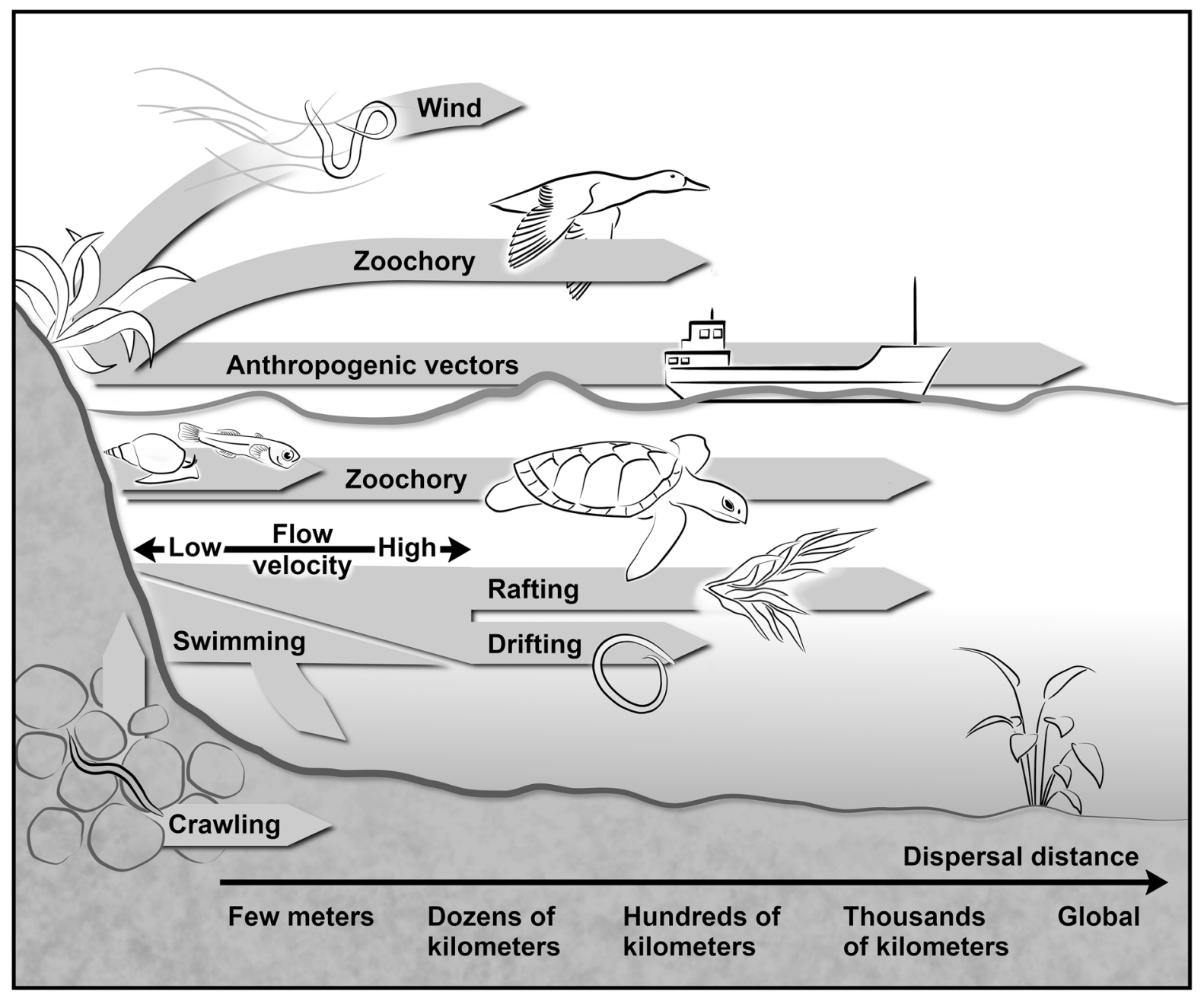

Fig. 1 Overview of the distribution modes and possible geographic ranges of nematodes based on the studies included in this review

of the worm (Wallace, 1968; Soetaert et al., 2002). With decreasing particle diameter, mobility is increasingly impaired because the interstitial spaces are narrower. In coarse sediment fractions, in which particle diameters exceed a third of the worm's length, locomotion is independent of particle size as the nematode then swims (Wallace, 1958, 1968). Thus, both sediment structure and nematode body width determine whether a nematode slides unimpeded through the interstitial or instead burrows (Wieser, 1959; Tita et al., 1999). In fine sediments with an incomplete interstitial system, nematodes with long, thin body shapes are at an advantage over those that are shorter and/or thicker. In addition to body length and width, the shape of the nematode tail provides insights into nematode locomotion, as long-tailed taxa exhibit greater mobility and maneuverability and are thus largely found in fine sediments (Thistle \& Sherman, 1985; Schratzberger et al., 2007).

In liquid medium, the wavelength, amplitude and frequency of the alternating contractions of nematodes are stronger and compensate for the reduced propulsion compared to that in sediments (Gray \& Lissmann, 1964). In the water column, for example, the propulsive thrust must exceed the nematode's body weight; otherwise the nematode will sink (Wallace \& Doncaster, 1964; Wallace, 1968). Small nematodes are better able to remain in the water column because, unlike larger individuals, their undulatory movement is not hampered by viscosity (Crofton, 1966). This was demonstrated experimentally by Ullberg \& Ólafsson (2003b) while Thomas \& Lana (2011) and Lins et al. 
(2013) reported that, congruent with determinations of the most mobile nematode morphotypes in sediment, active swimmers were those with thin, uniform, longtailed bodies. Together, these morphological adaptions suggest that nematode species disperse vertically and horizontally within the substrate to different extents and are able to enter the water column by active movement. Once in open water, nematodes can theoretically cover distances by swimming and then actively emigrate back to the sediment.

Little is known about the intrinsic speed of nematodes and most of the available studies have focused on terrestrial taxa (Table 1). Moreover, in most if not all cases, the speed of aquatic nematodes was assessed in liquid or unnatural media, such as agar, but not in natural sediments. Jensen (1981) determined a swimming speed of $50 \mathrm{~mm} / \mathrm{min}$ for the marine nematode species Chromadorita tenuis in still water. Another study showed that nematodes can swim continuously for at least $1-2 \mathrm{~h}$ (Ghosh \& Emmons, 2008). The crawling speed of nematodes on or through a substrate is significantly slower than the swimming speed (Table 1). For example, when placed on agar Panagrellus silusiae can bridge distances of $30 \mathrm{~mm}$ within $1 \mathrm{~min}$ (Gray \& Lissmann, 1964). The study of Hapca et al. (2007) convincingly showed that the crawling speed of nematodes in natural sediment is slower than that in or on agar. In

Table 1 Summary of studies that estimated the velocity (crawling or swimming) of different nematode species in different media

\begin{tabular}{|c|c|c|c|c|}
\hline Taxon & $\begin{array}{l}\text { Body length } \\
(\mu \mathrm{m})\end{array}$ & Medium & $\begin{array}{l}\text { Distance }(\mathrm{mm}) \\
\mathrm{moved} / \mathrm{min}\end{array}$ & References \\
\hline \multirow{2}{*}{$\begin{array}{l}\text { Caenorhabditis elegans } \\
\text { (Maupas, 1900) }\end{array}$} & Different sizes & In/on agar & $1-15$ & Ramot et al. (2008) \\
\hline & & In/on agar + food & $1-13.5$ & \\
\hline $\begin{array}{l}\text { Chromadorita tenuis (G. } \\
\text { Schneider, 1906) }\end{array}$ & $\sim 1,000$ & Water/swimming & 50 & Jensen (1981) \\
\hline \multirow{2}{*}{$\begin{array}{l}\text { Haemonchus contortus } \\
\quad \text { (Rudolphi, 1803) }\end{array}$} & 575 & On $2 \%$ agar & 3.1 & Gray \& Lissmann (1964) \\
\hline & & Water/swimming & 9.9 & \\
\hline \multirow{6}{*}{$\begin{array}{l}\text { Heterodera schachtii } \\
\text { (A.Schmidt, (1871) }\end{array}$} & Larvae $(<500)$ & On alginate jelly + & & Wallace (1958) \\
\hline & & $<1 \mu \mathrm{m}$ water film & $<0.05$ & \\
\hline & & $2-5 \mu \mathrm{m}$ & 1.7 & \\
\hline & & $5-10 \mu \mathrm{m}$ & 0.7 & \\
\hline & & $10-20 \mu \mathrm{m}$ & 0.3 & \\
\hline & & $50 \mu \mathrm{m}$ & 0.2 & \\
\hline \multirow{5}{*}{$\begin{array}{l}\text { Panagrellus silusiae (de } \\
\text { Man, 1913) }\end{array}$} & $1,190-1,340$ & On $1 \%$ agar & 30.1 & Gray \& Lissmann (1964) \\
\hline & & In $1 \%$ agar & 27.6 & \\
\hline & & On $1 \%$ gelatin & 17.5 & \\
\hline & & In $1 \%$ gelatin & 23.2 & \\
\hline & & Water/swimming & 38.4 & \\
\hline \multirow{2}{*}{$\begin{array}{l}\text { Phasmarhabditis } \\
\text { hermaphrodita (A. } \\
\text { Schneider, 1859) }\end{array}$} & $\sim 1,000$ & On $1.2 \%$ agar & 9.7 & Hapca et al. (2007) \\
\hline & & On $1.2 \%$ agar + sand & 6.9 & \\
\hline Rhabditis & & In a suspension of starch grains & $13.2-31.2$ & Gray \& Lissmann (1964) \\
\hline \multirow{3}{*}{$\begin{array}{l}\text { Turbatrix aceti (Müller, } \\
\text { 1783) }\end{array}$} & $1,500-1,570$ & On $0.5 \%$ agar & 15.4 & Gray \& Lissmann (1964) \\
\hline & & In $0.5 \%$ agar & 17.2 & \\
\hline & & Water/swimming & 43.1 & \\
\hline
\end{tabular}


that study, the movement of Phasmarhabditis hermaphrodita was reduced by $29 \%$, down to $6.9 \mathrm{~mm} /$ min, when a thin layer of sand was added to the agar. Among meiofauna, nematodes are rather slow, as copepods have a swimming speed of far over $400 \mathrm{~mm} /$ min and a burrowing speed of up to $16 \mathrm{~mm} / \mathrm{min}$ while the burrowing speed of oligochaetes may reach $13 \mathrm{~mm} / \mathrm{min}$ (Enright, 1977; Yen, 1988; Palmer et al., 1992).

\section{Surface adherence}

Surface adherence is another factor that can affect the dispersal ability of an organism. In nematodes, adherence is enabled by the adhesive substances secreted by the caudal glands, adhesive tubes or strong setae (Adams \& Tyler, 1980; Turpenniemi \& Hyvärinen, 1996; da Fonsêca-Genevois et al., 2006; Giere, 2009; Tchesunov, 2015). The anchoring ability of nematodes allows them to stably colonize hard substrates even in high-energy environments, such that subsequent dispersal is mostly via rafting.

\section{Behavior}

Nematode mobility is also influenced by water parameters, the availability of food resources and the community composition (e.g., Wallace, 1968; Robinson, 1994; Ramot et al., 2008), all of which may lead to short-term translocations. de Meester et al. (2012, 2015) conducted a series of standardized laboratory experiments and showed that at high densities nematodes begin to emigrate from their source habitat. In this context competitive strength between species plays a decisive role, as species that are weak competitors emigrate earlier and at higher densities than strong competitors. Emigration is also determined by the availability of suitable food resources, as it is discouraged by sufficient food at the source habit but stimulated by the absence of food and by the presence of more suitable sources in adjoining areas (de Meester et al., 2012). Tita et al. (1999) showed that different nematode morphotypes are associated with specific feeding groups, with smaller ratios of body width:body length typical of microvores and higher ratios characteristic of epigrowth feeders and predators.

Additional information on the dispersal behavior of nematodes comes from observations of their communities in natural environments. The oxygen content in benthic habitats is a crucial environmental factor that determines the dispersal depth of nematode communities (Platt, 1977; Strommer \& Smock, 1989; Hendelberg \& Jensen, 1993; Traunspurger, 1997; Teiwes et al., 2007). Studies from freshwater and marine environments have shown that nematodes mostly colonize the upper layers of the sediment, while in deeper layers, with their lower oxygen content, nematode density declines and their communities are composed by more adapted species. In wellaerated habitats, such as streams with a coarse ( $>125 \mu \mathrm{m}$ ) sediment size, relocation to deeper layers is possible (Schmid-Araya, 1997; Eisenmann et al., 1998; Traunspurger et al., 2015) and reduces the risk of erosion by a strong flow velocity (Palmer \& Gust, 1985; Palmer, 1986; Palmer \& Molloy, 1986; Fegley, 1987; Palmer, 1988a; Traunspurger et al., 2015). Consequently, the tidal cycle can trigger the daily vertical migration of certain species of marine nematodes. However, the upwards migration of some species when the tide is strongest (Steyaert et al., 2001; Gallucci et al., 2005; Brustolin et al., 2013) suggests that factors other than protection from erosion must be invoked to explain vertical migration. For example, the occurrence of specific feeding types is determined by the allocation and quality of food sources (Soetaert et al., 2002; Neira et al., 2013). This was also observed by Traunspurger et al. (2015), who found that bacterial-feeding taxa are restricted to the upper sediments of streams, as also demonstrated for epigrowth feeders (Commito \& Tita, 2002). Additionally, Traunspurger \& Drews (1996) detected a predominance of juvenile individuals in these habitats. Experiments have shown that the active movement of nematodes is influenced by the suitability of habitats (e.g., the presence of food resources, or habitat structure) (Jensen, 1981; Ullberg \& Ólafsson, 2003b; Lins et al., 2013; Mevenkamp et al., 2016). Thus, chemotaxis and the attraction of specific signal molecules (see also Choe et al., 2012 and literature therein) can be a powerful driver for the community composition of marine and freshwater nematodes.

The presence of predators and their physical disturbance of the sediment can restructure the distribution of nematodes and initiate active dispersal processes. Predators optimize their predation efforts by vertical migration while potential prey nematodes seek refuge in less vulnerable layers of the sediment 
(Steyaert et al., 2001; Gallucci et al., 2008). In the presence of copepods and chironomids in sediment, the relative number of nematodes, especially juveniles, in the upper layers significantly increased, caused by an induced vertical relocation (Traunspurger et al., 2006). Ólafsson (2003) described the opposing effects of different organismal groups, including crustaceans, annelids and mollusks, on nematode dispersal in sediments. In that study, the presence of larger organisms often led to the migration of nematodes into deeper layers. However, whether this was an escape from predation, or induced by the physical disturbance caused by the bioturbation, or a response to the improved aeration in the disturbed deeper sediment was unclear.

In general, most of the considered studies conducted in natural environments could not clearly show whether nematode migration was triggered directly by the respective factor or whether the change in the community structure was due to environmental filtering. Further studies that minimize influencing factors such as emigration from adjacent areas or reproduction and, in the best case, allow observations of migratory nematodes (according to de Meester et al., 2012, 2015) would be an approach to investigate the distribution behavior of nematodes in response to certain environmental factors.

\section{Dispersal units}

According to Fontaneto (2019), the successful longrange dispersal of meiobenthic sized organisms requires, inter alia, the presence of propagules and the long-term resistance of these dispersal units. Propagules are especially relevant to dispersal outside the water (e.g., wind drift) (Panov et al., 2004; Nkem et al., 2006; Incagnone et al., 2015). For nematodes, dormant eggs, dauer larvae and stages of anhydrobiosis that facilitate resistance to high temperature, frost, desiccation and digestion (see the "Endozoochory" section) for periods partly as long as several decades (van Gundy, 1965; Watanabe, 2006; Mayer \& Sommer, 2011) are of particular importance (Fontaneto, 2019). However, while eggs and dauer larvae are common dispersal units of nematodes, anhydrobiosis is known from other aquatic invertebrates such as microcrustaceans or rotifers. However, for nematodes anhydrobiosis is mainly restricted to terrestrial species and colonizers of ephemeral aquatic habitats (e.g., ponds) and is not a feature of species found in stable aquatic environments (Crowe \& Madin, 1974; McSorley, 2003; Watanabe, 2006; Tahseen, 2012).

Several studies have investigated egg production by different freshwater nematodes and reported values of up to 49 eggs/day (Schiemer et al., 1980; Muschiol \& Traunspurger, 2007; Kreuzinger-Janik et al., 2017). Those studies also showed that the number of laid eggs is strongly species-specific and depends on the age of the female nematode but also on environmental parameters (e.g., availability of food resources). As the hatching of juveniles is triggered by factors that include temperature and moisture, it can be delayed until environmental conditions are optimal (van Gundy, 1965). Egg clusters with sticky membranes are protected from dehydration or erosion and can thus be dispersed by rafting or zoochory (see later sections in this review) (Micoletzky, 1922; van Gundy, 1965).

\section{Active dispersal through the sediment}

Kappes et al. (2014) compared the dispersal potential of aquatic and terrestrial taxa (plants, mollusks, gastropods and dipterans) and showed that the former are especially successful in covering long distances. For organisms of meiobenthic size, dispersal mainly relies on passive modes (Incagnone et al., 2015), whereas in the case of active movement the maximal dispersal distance declines with decreasing body size (Jenkins et al., 2007).

The dispersal of nematodes through the sediment has been less intensively studied than dispersal in the water column. In studies on the recolonization of sediments by meiofauna (Table 2), the immigration of sediment-crawling organisms was often prevented by the placement of azoic sediments on impassable barriers such as trays. Chandler \& Fleeger (1983) were the first to demonstrate that the degree of immigration of nematodes in azoic sediments by sediment crawling and water column dispersal was very similar in a tidal pond. However, whereas nematodes were the predominant meiofaunal taxon in the undisturbed sediment $(>80 \%)$, with an abundance sufficient to allow recruitment, even after 29 days their densities in the azoic sediment were less than a third of those in the source sediment. The further demonstration that even copepods, which are very effective dispersers in the water column, could 


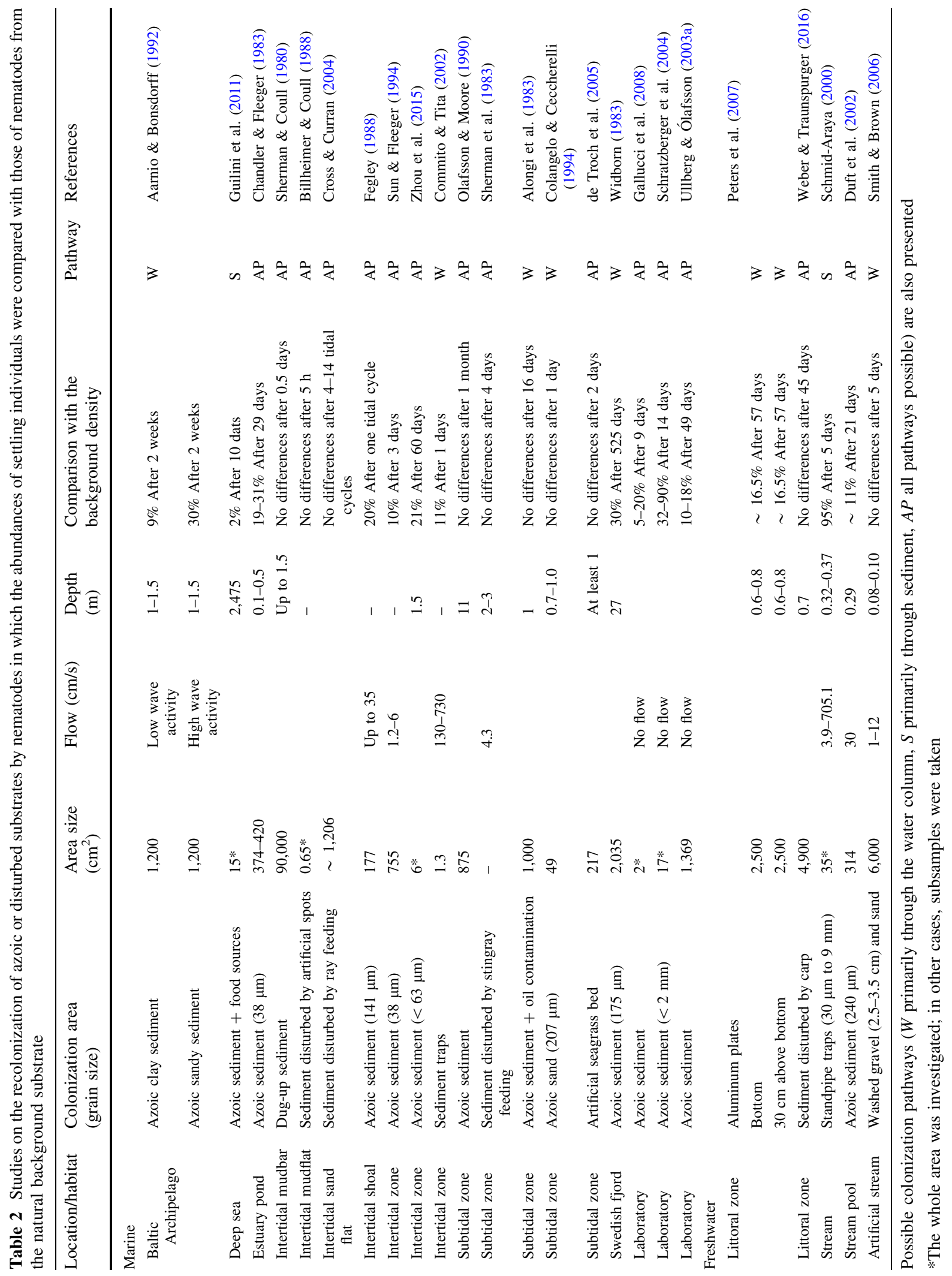


not approximate their sediment density during the same period showed that colonization through the sediment is a slow process. Much higher recolonization rates for nematodes were reported by SchmidAraya (2000) in a study of a fast-flowing stream with coarse gravel. In that setting, recolonization by nematodes and harpacticoids was completed within 5 days and that by other meiofaunal organisms (cyclopoids, rotifers and ostracods) within approximately 2 days. Whether this immigration was primarily due to downstream movement was not investigated. Although other studies of azoic stream sediments found evidence of nematode colonization by upstream movement (Williams \& Hynes, 1976; Williams, 1977), migration by downstream drift cannot be excluded because in those investigations the $125-\mu \mathrm{m}$ nets used to prevent immigration from other directions would not have been an effective barrier for nematodes.

Active dispersal in the sediment includes not only horizontal movement but also vertical displacement. Nematodes in sediments exhibit a typical vertical distribution, with time-related and species-specific vertical preferences discerned in seasonally affected habitats such as streams or the littoral and profundal of lakes (Traunspurger \& Drews, 1996; Traunspurger et al., 2015). The constant upward and downward dispersal of nematodes within relatively short time intervals may allow the colonization of deposed substrates from below. Using the same experimental design, Williams \& Hynes (1976), Williams (1977) and Benzie (1984) showed that up to $62 \%$ of the immigrating nematodes that had colonized the azoic substrates had done so by vertical movement.

The importance of crawling in the sediment

Both Schratzberger et al. (2004) and Gallucci et al. (2008) found that large (long and wide) nematodes are the first to enter azoic sediment by sediment burrowing. The two studies also showed that active dispersal has significantly different effects on the species composition of the recolonized and source sediments. Thus, despite the strong influence of active crawling on nematode diversity, this type of motility is restricted to small areas around the source habitat. In the study of Ullberg \& Ólafsson (2003a), the number of nematodes arriving at a location $36 \mathrm{~cm}$ away was only half that at an area adjacent to the source habitat.
Among the studies on the recolonization of the azoic substrates listed in Table 2, only one was able to attribute the alignment (95\%) of nematode densities in the new vs. the background substrate to in-sediment movement alone. Accurate insights into the active spread of organisms within the sediment will require further studies that specifically examine this pathway.

Nematodes are classified as mainly passively dispersed organisms. While this applies to large distances, active movement over smaller ranges should not be underestimated, as demonstrated in a study of the colonization of disturbed habitats after predation (Weber \& Traunspurger, 2015). The advantages of active locomotion include that emigration is determined by the organism itself, adverse environmental conditions can be avoided, and favorable conditions directly pursued. However, the active dispersal of nematodes in sediments is restricted to station-keeping movement within a home range (according to Schlägel et al., 2020) and is largely associated with behavior patterns such as foraging or reproduction (see the "Behavior" section). As such, because it is unlikely to result in spatial gene flow, it does not correspond to the definition of dispersal provided above.

\section{Nematodes in the open water}

Numerous studies have described the presence of nematodes in open waters. For example, Mott \& Harrison (1983) collected up to 46,000 nematodes $/ \mathrm{m}^{3}$ in a fast-running stream. In a very early study by Eddy (1927) and a much later one by Abdel-Aziz \& AboulEzz (2004), the number of nematodes in plankton samples from lake littorals was as high as 11,000 nematodes $/ \mathrm{m}^{3}$. Nematode densities in the water column are summarized in Table 3 . In several of the cited studies, nematodes are only casually mentioned or are discussed as bycatch obtained by resuspension of the sediment during sampling (e.g., Fernando, 1980; Dimas-Flores et al., 2008).

The majority of studies describing nematodes in open waters were conducted in relatively high-energy environments, i.e., those affected by wind, waves, tides or waterflow along a stream, and in most cases samples were obtained at heights not more than $1 \mathrm{~m}$ above the substrate. Boeckner et al. (2009) demonstrated that with increasing height above the substrate 


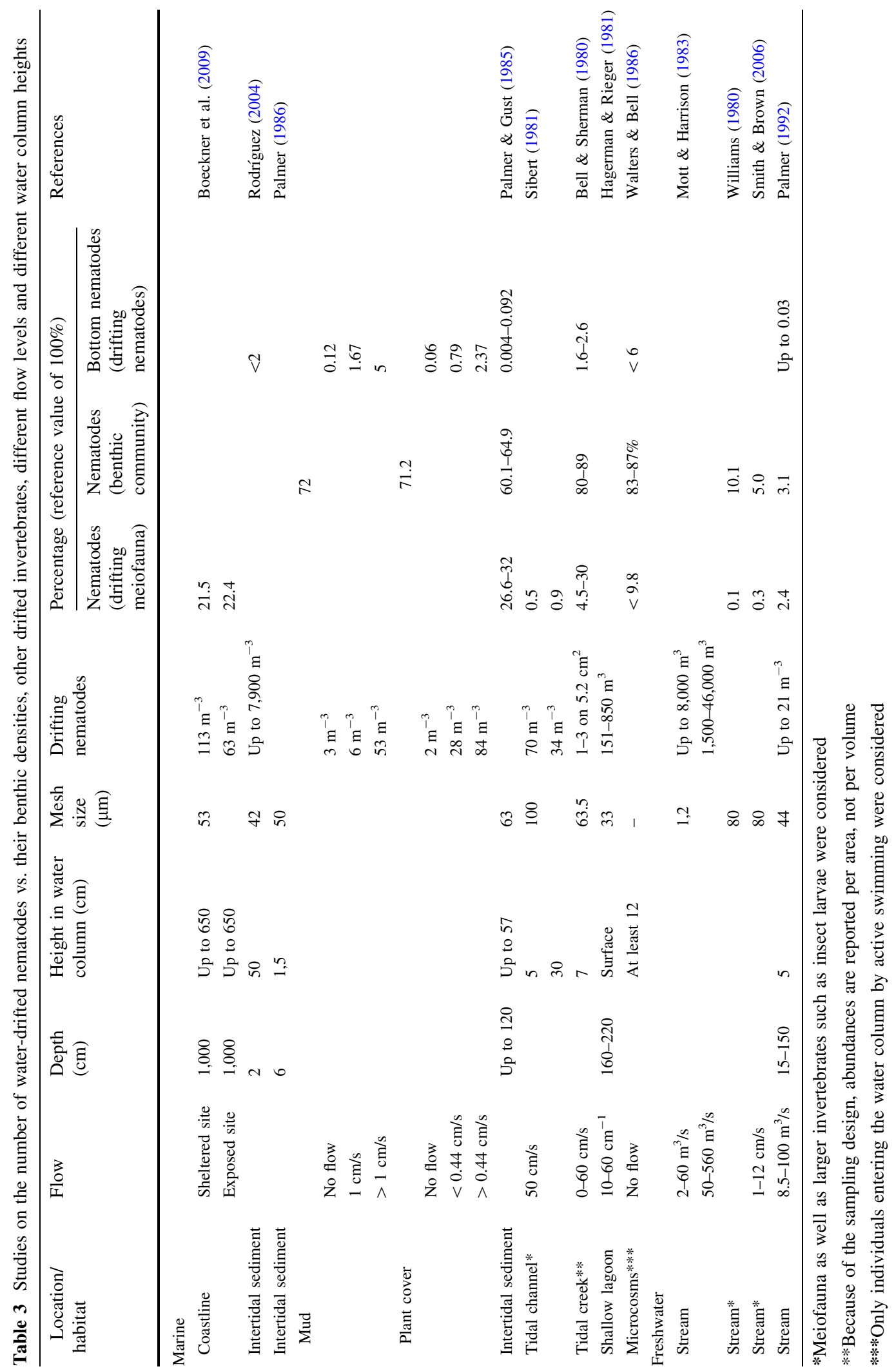


the number of nematodes in the water column declines. In that study, $58 \%$ of the nematodes were collected at a height of $0.5 \mathrm{~m}$ but only $2 \%$ above $6.5 \mathrm{~m}$. Most of the organisms in the water column are apparently directly $(<5 \mathrm{~cm})$ above the ground (Sibert, 1981). However, even water layers not in direct exchange with the substate may contain nematodes. This was shown by Khalifa et al. (2015), who detected nematodes at a height $>15 \mathrm{~m}$ above the lake bottom. In the open ocean, nematodes may be associated with marine snow, which can also be found a few meters below the surface (Shanks \& Walters, 1997).

Nematodes typically account for $<33 \%$ of the meiofauna in open water (Table 3 ) whereas copepods and, in streams, rotifers and chironomid larvae are encountered above the substrate in higher numbers. For example, Palmer (1992) reported that only $2.4 \%$ of the drifting meiofauna collected in a fourth-order stream were nematodes, while rotifers, oligochaetes, chironomids and copepods represented $86.2 \%, 6.9 \%$, $2.9 \%$ and $1.5 \%$, respectively. These latter organisms are more efficient active dispersers and have higher dispersal rates (Palmer, 1988a; Commito \& Tita, 2002; da Fonsêca-Genevois et al., 2006). As shown in Table 3, most nematodes remain in the substrate, with $<3 \%$ reaching the open water. However, given the high abundance of nematodes in the substrate, the resuspension of even a small percentage may be sufficient for an effective dispersal in the water column. According to Artois et al. (2011), 300 million nematodes representing 38 freshwater species are transported in the Adda River per day. However, the composition of those species in the open water may not be entirely congruous with the composition within the substrate (Commito \& Tita, 2002; da FonsêcaGenevois et al., 2006). Therefore, either specific taxa enter the water column by active movement or not all species are passively suspended.

\section{Active emigration from sediment}

Active entry into open water has been investigated in microcosm experiments without any flow and thus able to exclude passive processes. Jensen (1981) examined active emigration from the substrate and was able to demonstrate that nearly all nematodes left the sediment and swam $5 \mathrm{~cm}$ upwards, in the direction of food sources. In the studies of Alldredge \& King (1977) and Walters \& Bell (1986), only a small fraction of the natural nematode composition $(<6 \%)$ entered the water from the sediment when no food sources were offered. Armonies (1988a) similarly showed that in the absence of a food incentive nematodes did not leave the sediment; however, $96 \%, 65 \%$ and $35 \%$ of the copepods, ostracods and flatworms, respectively, actively emigrated within $24 \mathrm{~h}$.

The entry of meiobenthic organisms into the water column may depend on the time of day. Palmer (1992) and Armonies (1994) found that copepods, oligochaetes and rotifers mainly leave the sediment during nighttime, consistent with active emigration, while a similar behavior was not exhibited by nematodes. Clifford (1972) collected higher numbers of meiobenthic organisms, including nematodes, from the water column during the day, but whether the time of day influenced nematode emigration could not be established.

\section{Passive emigration from sediment}

A widely discussed factor in the passive emigration of nematodes into open water is erosion by flow. An increase in the number of nematodes and other meiobenthic organisms in the open water with increasing flow (e.g., tidal cycles, wave action, storms or flood events) was demonstrated in several studies of freshwater and marine habitats (Mott \& Harrison, 1983; Palmer, 1986; Armonies, 1988b; Palmer, 1990; Armonies, 1994; Ullberg, 2004; de Meester et al., 2018). The dispersal of other meiofauna, mainly copepods, is significantly less dependent on flow velocity because these organisms have a higher potential for active dispersal into the water column (Palmer, 1988a; Commito \& Tita, 2002). Near-bed flow and the resultant shear stress have an especially strong impact on organismal transport (Eckman, 1983; Palmer, 1986). However, for the erosion of nematodes from sandy sediment, relatively low flow velocities of 9-12 cm/s are sufficient (Palmer, 1992; Thomas \& Lana, 2011) and even a flow rate of $<3 \mathrm{~cm} / \mathrm{s}$ allows the resuspension of single nematodes (Armonies, 1988b). The threshold for the erosion of nematode individuals can be less than that for the surrounding sediment; thus, nematodes are not only eroded together with the sediment but are also leached from the sediment (Palmer, 1992). For flatworms and copepods, abundances in the water column are highest 
at low flows (Armonies, 1994), indicating a larger role of active emigration. However, as more nematodes are not consistently resuspended in high-energy vs. lowflow habitats (Boeckner et al., 2009), additional factors must also determine the number of eroded nematodes.

Alldredge \& King (1977) observed a higher transfer of nematodes to the open water above fine, sandy sediments than above coarse particles, although similar velocities were measured at the two sites. Because the critical erosion threshold is lower in fine, sandy sediments, nematodes are probably removed together with the sand, while coarser sediment would provide protection up to a certain flow level. Near-bed hydrodynamics are mainly affected by the topography of the sediment and the presence of above-ground structures (e.g., plants) (Eckman, 1983). For example, sediment-covering vegetation and surface depressions lower the shear stress, thus reducing the erosion of small organisms while simultaneously enhancing passive immigration by the deposition of nematodes and other meiobenthic organisms (Anderson \& Charters, 1982; Fonseca et al., 1982; Eckman, 1983; Nowell \& Jumars, 1984; Atilla et al., 2005).

Nematodes of the upper sediment layers are highly likely to be resuspended (Eskin \& Palmer, 1985; Palmer, 1988a; da Fonsêca-Genevois et al., 2006; Thomas \& Lana, 2011). While thin, agile taxa avoid erosion by migrating to deeper areas, more lethargic nematodes (especially epistrate feeders) remain in the surface sediment and are washed away (Eskin \& Palmer, 1985; Tita et al., 1999; Thomas \& Lana, 2011) and their dispersal rates are accordingly higher (Olafsson \& Moore, 1990; Commito \& Tita, 2002). Therefore, the active vertical distribution of nematodes within the substrate (see the "Active dispersal through sediment" section) determines their passive dispersal by water drift. While, as discussed above, the presence of predators in the sediment contributes to shaping the vertical distribution of nematodes and other meiobenthic organisms, few studies have investigated the impact of predators on meiofaunal dispersal. Ullberg \& Ólafsson (2003a) found that the presence of amphipods had no effect on the active dispersal of nematodes. Since their study was conducted in microcosms without flow, passive dispersal processes could be excluded. By contrast, potential predators (fish, Leiostomus xanthurus) in more energetic habitats significantly increase the number of nematodes and other meiobenthic taxa (copepods and foraminiferans) in the water drift (Palmer, 1988b). This can be explained rather by the biting behavior of bottom-feeding fish, which would result in the resuspension of the nematodes, than by active emigration. Other types of fish, rays, sharks, manatees, walruses, waterfowl and even some whales can also cause large sediment disturbances and thus favor a considerable erosion of small benthic organisms. Such disturbances can alter the vertical distribution of meiofauna and enhance the water dispersal of deep-sediment-dwelling taxa.

\section{Drifting}

Unlike the emigration of nematodes from the substrate to the open water, which can include active and passive components, subsequent transfer in high energetic and possibly also low flow freshwater and marine systems is primarily due to passive drift (Palmer, 1984; Palmer \& Gust, 1985; Palmer, 1990). In high-energy habitats, the transfer and emigration of nematodes and other meiobenthic organisms such as copepods can be attributed to passive particles because even a low flow velocity can prevent active progress (Hagerman \& Rieger, 1981; Palmer \& Gust, 1985). This was convincingly demonstrated by Palmer (1990), who showed equal sinking/swimming rates of living and anesthetized nematodes $(0.09 \mathrm{~cm} / \mathrm{s})$. Flood events can also cause organisms to drift between waters that are otherwise spatially isolated. This dispersal mode is relevant for several aquatic taxa, including zooplankton (Dias et al., 2016), macrobenthos (Petsch et al., 2017) and macrophytes (Akasaka \& Takamura, 2012), and can markedly influence their local species composition. The spread of nematodes through flooding has not been reported so far but is likely.

\section{Transfer back to the substrate}

Although nematodes in the open water have essentially no influence on the direction of their journey, they can delay their sedimentation until suitable substrates are in range. The body length, flexibility, activity level and adhesiveness of nematodes are essential factors that determine where nematodes become deposited in the sediment (Bertelsen, 1997). Species with the morphological adaptions that allow 
swimming (slim body, long tail) remain in the open water longer than less active species (de Meester et al., 2018). In addition, specific behaviors, such as coiling, which reduces the projected body area of the organism, can enhance the sinking rate (Bertelsen, 1997). The accumulation of drifting nematodes attached to objects (see the "Rafting" section) or to larger organisms (see the "Animal dispersal vectors" section) can increase the time spent in the open water. Active immigration into substrates by swimming was observed in laboratory investigations only under noflow conditions (Jensen, 1981; Ullberg \& Ólafsson, 2003b; Lins et al., 2013; Mevenkamp et al., 2016), but all of those studies consistently showed that the settling locations were those with the most suitable food sources or habitat structure.

Palmer (1984) estimated the passive settlement rate of nematodes and reported a settling velocity (calculated for the total meiofauna) of $\sim 0.15 \mathrm{~cm} / \mathrm{s}$. However, in that study only $36 \%$ of the nematodes in the water column were returned to the sediment. In the study of Commito \& Tita (2002), emigration rates of drifting nematodes ranged from 1 to 135 individuals/ $\mathrm{cm}^{2} /$ day and were mainly influenced by the background densities in the sediment and by the flow velocity. At higher flow rates, more nematodes were collected in bottom traps. As already noted, depressions (e.g., bottom traps, feeding pits, tunnels of sediment dwellers) promote immigration back to the sediment. According to Palmer (1986), benthic organisms can affect the roughness of the substrate by reworking processes and thus influence the critical erosion velocity, as demonstrated for invertebrates such as crabs and polychaetes (Luckenbach, 1986; DePatra \& Levin, 1989) but also for fish (Sherman et al., 1983; Billheimer \& Coull, 1988; Cross \& Curran, 2004). The latter studies examined the recolonization of fish feeding pits by meiofauna and showed that nematode densities in the disturbed area became comparable to those in the surrounding sediment within a relatively short time $(5 \mathrm{~h}$ to 7 days, see Table 2), presumably due to the suitable hydrodynamic conditions around the pits and the lower shear stress.

Atilla et al. (2005) demonstrated that artificial above-ground structures (e.g., bottle brushes) retain drifting organisms. With the increasing complexity of the structure (in this case, bristle density), both the retention and diversity of the captured nematodes increase significantly due to flow reduction.
Importance of drifting

The distances covered by drifting nematodes are difficult to determine because tracking over longer distances under field conditions is challenging. To our knowledge, only Thomas \& Lana (2011) were able to localize the exact source of nematodes collected from the water column. In that study, stained nematodes were trapped $2 \mathrm{~m}$ away from the site of their release. Bell \& Sherman (1980) and da Fonsêca-Genevois et al. (2006) determined the distance to the next known natural occurrence of the collected species and concluded that nematodes are able to cover distances of $500 \mathrm{~m}$. Both Hagerman \& Rieger (1981) and Derycke et al. (2007) reported distances of at least $10 \mathrm{~km}$. In general, the studies presented in this section suggest that the continuous transport of small organisms (planktic and benthic) by drift occurs in all bodies of waters with a minimal flow velocity. Furthermore, for organisms with the necessary traits (e.g., propagules), drift enables a long-range dispersal as well as translocation between waters and may thus be the most important transport mode for nematodes and other mainly passively dispersed aquatic organisms.

\section{Rafting}

Rafting, the passive transport of organisms on floating biotic (e.g., algae, driftwood, marine snow) or abiotic (e.g., plastic debris or tar balls) items, is a common dispersal mode for a wide range of terrestrial and aquatic vertebrates as well as invertebrates in marine and fresh waters (Thiel \& Gutow, 2004b). The organic items frequently derive from benthic habitats that were detached by water flow or wind, such that they contain a complete organismal community. On the other hand, the raft may be initially unoccupied, as is often the case for anthropogenic items. In both cases, new organisms may arrive on the raft during its journey (Thiel \& Gutow, 2004b). Rafting nematodes are mainly transported on floating substrates (algae, bacterial mats, marine snow) or on vehicles with at least temporal contact with the benthos (e.g., ice; Macfarlane et al., 2013) (Table 4).

Rafting is an important dispersal mechanism that enables the transfer of organisms especially between shore areas (Thiel \& Gutow, 2004a, b), given the erosion of benthic substrates together with their 
Table 4 Investigations of marine and freshwater environments in which rafting nematodes were found on different floating items

\begin{tabular}{|c|c|c|}
\hline Habitat & Floating substratum & References \\
\hline \multicolumn{3}{|l|}{ Marine } \\
\hline Estuary & Algae & Phillips (1963) \\
\hline Offshore waters $>100 \mathrm{~km}$ & Algae & Abe et al. (2013) \\
\hline Offshore waters $0.9-115 \mathrm{~km}$ & Algae & Ingolfsson (1995) \\
\hline Microcosms & Algae & Arroyo et al. (2006) \\
\hline Microcosms & Algae & Highsmith (1985) \\
\hline Shallow embayment & Algae & Ólafsson et al. (2013) \\
\hline Diff. habitats in the Sargasso Sea & Algae & Micoletzky (1922) \\
\hline Shallow archipelagic waters & Algae & Norkko et al. (2000) \\
\hline Oligohaline eulittoral zone & Bacterial mats & Vopel \& Arlt (1995) \\
\hline Bermuda Islands & Coconut & Gerlach (1977) \\
\hline Mangrove embayment & Detritus & Faust \& Gulledge (1996) \\
\hline Intertidal mudflat & Ice & Macfarlane et al. (2013) \\
\hline Pack-ice & Ice & Schünemann \& Werner (2005) \\
\hline Offshore waters $3 \mathrm{~km}$ & Marine snow & Shanks \& Walters (1997) \\
\hline Shallow bay & Marine snow & Shanks \& Edmondson (1990) \\
\hline Sheltered intertidal sandflat & Seafoam & Armonies (1989) \\
\hline Tidal drainage channel & Sediment & Hicks (1988) \\
\hline \multicolumn{3}{|l|}{ Freshwater } \\
\hline Pond & Algae & Phillips (1958) \\
\hline Stream & Bacterial biofilm & Gaudes et al. (2006) \\
\hline Cave waters & Bacterial mats & $\begin{array}{l}\text { Riess et al. (1999); Muschiol et al. } \\
\text { (2015) }\end{array}$ \\
\hline Mesocosm & Periphyton mats & Liston (2006); Liston et al.(2008) \\
\hline Stream & Water hyacinths & Sazima \& Zamprogno (1985) \\
\hline
\end{tabular}

resident organisms that mainly occurs in high-energy waters. Rafts washed up on the shore may be colonized by the benthic community and then drifted by water flow. In low-energy and shallow shore environments, substrate fragments that float up during the daytime via photosynthetic processes may be relocated by wind and then sink to the bottom at night, thereby enabling at least a short-term dispersal (Phillips, 1958; Faust \& Gulledge, 1996). The sinking rate of nematodes rafting on marine snow was temporally lower than of free-drifting nematodes but, which enabled their longer persistence in the water column (Shanks \& Edmondson, 1990).

Ingolfsson (1995) and Abe et al. (2013) found living nematodes on floating algae $>100 \mathrm{~km}$ away from the shoreline, indicative of long-range transport across the ocean. Covered distances of hundreds of kilometers have also been determined for other organisms, including oligochaetes and plathelminths (reviewed by Thiel \& Gutow, 2004b). In addition to wind and flow velocity, the durability of the floating item can limit the covered distance. For example, sea foam mediates a short dispersal as it quickly decays (Armonies, 1989) whereas more durable items, such as floating algae and especially driftwood, persist over many years and favor longer dispersal distances (Thiel \& Gutow, 2004a).

\section{Requirements for successful rafting}

Studies on nematodes on floating items from coastal waters showed their lower abundance and different species composition compared to nematodes in the substrate below (Hicks, 1988; Arroyo et al., 2006). For example, Faust \& Gulledge (1996) found that although nematodes were the predominant taxon in the upper sediment $(\sim 2,740$ individuals/l), only $\sim 1 \%$ of that population was present on floating detritus, where they accounted for $\sim 7 \%$ of the rafting metazoans, which were dominated by crustacean larvae $(\sim 87 \%)$. By 
contrast, Gaudes et al. (2006) reported significantly higher nematode densities on floating bacterial mats (up to 752 individuals $/ \mathrm{cm}^{2}$ ) than on attached mats. Since in many cases only single individuals are transported (Micoletzky, 1922; Abe et al., 2013), it is likely that not all nematodes associate with the raft or that some become lost during the voyage, resulting in a sorting process for rafting species.

Thiel \& Gutow (2004b) described the three features that determine the rafting of organisms: (1) the ability to cling to the potential raft, (2) successful survival on the raft and (3) the establishment of persistent populations during transport. For nematodes, their caudal glands and the adhesion of their eggs allow them to withstand the water flow and to remain on the raft for long periods of time (Micoletzky, 1922). Biotic rafts tend to host high densities of microfauna, including bacteria, protozoans, diatoms, and other algae, that constitute the basis of the rafting food web. The review of Thiel \& Gutow (2004b) also noted the presence of predatory, grazing and detritivore organisms on rafts, but suspension feeders able to optimally exploit the renewable resources predominated. Accordingly, studies on rafting nematode communities mostly identified bacteria- and algae-feeding species (Micoletzky, 1922; Riess et al., 1999; Gaudes et al., 2006; Muschiol et al., 2015). However, Micoletzky (1922) observed that the body sizes of nematodes on floating macroalgae were smaller than those of related species in the sediment. The authors attributed this finding to the limited food resources during long-range dispersal. Furthermore, during their voyage, rafting organisms are exposed to competition and predation as well as rapidly changing environmental parameters (e.g., flow velocity, temperature, salinity, UV radiation) (Thiel \& Gutow, 2004b). Nonetheless, with their ability of parthenogenetic reproduction, especially in freshwater environments, nematodes are able to compensate for losses and establish durable populations (Thiel \& Gutow, 2004b).

In contrast to drifting organisms, the chance of surviving long-range dispersal is higher for rafting individuals and whole communities, especially if structure-forming or engineering species colonize the raft. Reproduction during transfer will result in more individuals reaching a new habitat simultaneously, thereby facilitating its colonization. Nematodes investigated in a microcosm study showed almost no tendency to leave floating algae and recolonize the underlying sediment, as also reported for other organisms (Arroyo et al., 2006 and literature therein). However, in that study, whether the algae had direct contact with the sediment, thus enabling active immigration, or colonization was possible only over the water column was not resolved. Shanks \& Edmondson (1990) found that $94 \%$ of the vertical nematode flux in a shallow bay was due to individuals rafting on marine snow.

\section{Animal dispersal vectors}

Dispersal by larger animals consists of transfer on those organisms (epizoochory) or within their digestive tracts (endozoochory). In epizoochory, contact of the animal with nematode-containing water, substrate or other structures (e.g., plants) suffices to initiate transfer. In general, the overland transport on/in invertebrates and vertebrates is especially relevant for the meiofauna of littoral zones, wetlands, mudflats and other shallow waters, where direct contact with the sediment is likely. The dispersal distance resulting from zoochory depends on the range of the transporting animal, which for birds can be $\sim 1,000 \mathrm{~km}$. Processes that may limit epizoochory include dehydration. In the case of endozoochory, success requires the survival of ingestion (by direct predation or as bycatch) and digestion whereas subsequent transfer may be limited by the time required until digestion or the next defecation.

\section{Epizoochory}

Frisch et al. (2007) suggested that the transport of meiobenthic organisms on the feathers and feet of birds is more decisive than endozoochory. While this has been documented for benthic taxa such as cladocerans, copepods and bryozoans (Green \& Figuerola, 2005 and literature therein), it may not be the case for nematodes (Maguire, 1959). However, the use of coarse-meshed sieves for organism collection could have resulted in insufficient sampling and therefore biased conclusions.

Nematodes can also be dispersed via their transport in the fur of mammals. Vanschoenwinkel et al. (2008c) identified nematodes, rotifers copepods, ostracods, cladocerans, tardigrades and flatworms in the fresh mud left behind by wild boars on the trees 
they had rubbed themselves against. However, that study did not differentiate between living individuals and eggs, and nematodes accounted for only a very small percentage $(1 \%)$ of the collected meiobenthic organisms, which consisted mostly of microcrustaceans. Nematodes were the only taxon that did not emerge from boar feces incubated in water, indicating the complete digestion of living individuals and their eggs. Meiobenthic organisms have also been detected on the fur of nutrias (Waterkeyn et al., 2010a), whereby the percentage of nematodes was $<1 \%$ (five nematodes collected from three nutrias). While mammals of a large number of taxa can be assumed to transport meiobenthic organisms, current evidence suggests that fewer nematodes are transferred by mammals than by birds.

Another mode of dispersal is via turtle shells, as the backs of marine turtles are colonized by a diverse array of micro-, meio-, and macrobenthic organisms, all of which are associated with food webs and energy flows (Corrêa et al., 2014; dos Santos et al., 2018; Ingels et al., 2020). In contrast to all other dispersal modes discussed herein, apart from rafting, turtle shells allow the reproduction of the transferred organisms. Nematodes may reach densities on turtle shells of 21.6 individuals $10 \mathrm{~cm}^{-2}\left(1.08 \mathrm{~m}^{2}\right.$ shell size $)$ on average, with up to 41 genera/species per shell, and were the third most dominant taxon, behind ostracods and copepods. Although the meiobenthic community on turtle shells resembles that occurring in reef environments, turtle shells represent hotspots of nematode diversity. Moreover, because millions of turtles, with their standing stock of meiobenthic organisms, traveling thousands of kilometers between foraging grounds and nesting beaches (Luschi et al., 2003; Ingels et al., 2020), they must be considered as one of the most important epizoochoric dispersal vectors in marine environments.

Given the success of this dispersal pathway, other animals with outer shells or carapaces may also disperse nematodes by epizoochory. For example, Schejter et al. (2011) described nematodes associated with ascidian colonies on the shells of gastropods. Other epibiontic organisms, such as rotifers and protozoans, have also been found on various crustaceans, including aquatic sow bugs, lobsters and the crustaceans living on whales (Fernandez-Leborans \& Tato-Porto, 2000a, b; Fernandez-Leborans, 2001; Cook et al., 2002).

\section{Endozoochory}

Intact nematodes ingested by insect larvae, juvenile fish or crustaceans usually do not survive gut passage but are instead quickly (20 min up to hours) digested beyond recognition (Alheit \& Scheibel, 1982; Hofsten et al., 1983; Scholz et al., 1991; Muschiol et al., 2008; Ptatscheck et al., 2015b; Weber \& Traunspurger, 2017, 2015). However, this is not the case for all nematode species. The free-living nematode Panagrellus redivivus survives in the gut of larval coregonids for a few hours and is able to pass through the intestine, leaving by active movement (Schlechtriem et al., 2005). Nematodes exiting the fish gut are subsequently located in the open water, which enables their further dispersal (water drift, rafting or swimming). Similarly, unscathed gut passage has been reported for numerous Rhabditida species ingested by gastropods (Sudhaus, 2018), with the nematodes surviving for up to 5 days until their excretion. Gastropods exert strong top-down effects on the meiofaunal communities of periphyton (Burgmer et al., 2010; Schroeder et al., 2010; Peters \& Traunspurger, 2012; Schroeder et al., 2013), which implies the regular consumption and thus the endozoochory of nematodes. Transport by fish larvae and gastropods provides a larger dispersal radius for nematodes than allowed by their own locomotion but not a dispersal over long distances or between different waters, as occurs with transport by birds. Gaston (1992) found up to 2,300 nematodes and 5,000 copepods in the gut of waterfowl (green-winged teal) that had fed for $20 \mathrm{~min}$ on a mud flat. Overall, nematodes together with ostracods and copepods represented up to $36 \%$ of the ingested meiofauna, which was about the same proportion as collected from $1 \mathrm{~m}^{2}$ of sediment from the examined area. An analysis of waterfowl feces revealed living adult nematodes but their occurrence strongly varied between bird species (3-60\%) and their numbers increased after several days when the feces were incubated in water (Green et al., 2008). The latter observation leads to the conclusion that some nematodes survived the passage as propagules, probably as eggs, as also suggested by the investigation of Frisch et al. (2007). According to the results of Green et al. (2008), the feces of one grey goose may contain $\sim 13$ nematode individuals, but considering that a flock of waterfowl at a particular site may comprise several thousand individuals, the transfer of 
meiobenthic organisms by endozoochory may well be substantial. Additionally, this study also showed that the eggs of crustaceans are found much more frequently and in greater numbers in the feces of waterfowl than nematodes.

In addition to primary zoochory, secondary zoochory via the seeds and invertebrates (e.g., daphnia) ingested by fish and dispersed by piscivorous birds such as cormorants has been described (van Leeuwen et al., 2017). However, this pathway has not yet been demonstrated for nematodes or other typically meiobenthic organisms.

Hessen et al. (2019) concluded that the only conceivable vector for the long-distance endozoochory of pelagic microcrustaceans is waterfowl, which can cover distances of hundreds of kilometers. Nonetheless, the authors also noted that this dispersal pathway is less likely because of the different feeding grounds (the birds forage in terrestrial or coastal habitats) and the fast gut turnover of these birds, but dispersal over short distances was likely to be common.

\section{Gone with the wind}

An omnipresent vector for the overland dispersal of unicellular organisms (e.g., bacteria, algae) and microscopic metazoans (e.g., nematodes, microcrustaceans, flatworms, acari, rotifers) is wind (Frankland, 1886; Vanschoenwinkel et al., 2008b). Wind erosion primarily affects terrestrial organisms, while inhabitants of benthic habitats are exposed to wind mostly in eulittoral zones, floodplains, desiccated substrates and thus especially in temporal waters and semiaquatic habitats (e.g., ponds or phytotelmata).

In contrast to other benthic organisms or zooplankton, there is little consistent information on the wind drift of nematodes, especially regarding the resultant dispersal rates (individuals collected at a certain time in a certain area). Furthermore, many of the studies did not identify nematodes to the genus/species level, which complicates determination of their source and favored habitat. To the best of our knowledge, only Ptatscheck et al. (2018) examined nematodes from aquatic habitats drifted by wind. Among the 27 winddispersed nematode species that were collected, only 1 preferentially colonized aquatic environments whereas at least 9 were known from both terrestrial and aquatic or semiaquatic habitats. The most common species were typically terrestrial, consistent with the results of other studies (Baujard \& Martiny, 1994; Nkem et al., 2006).

While in the study of Vanschoenwinkel et al. (2008a) nematodes accounted for $\sim 1 \%$ of the aeroplankton ( $\sim 94 \%$ crustaceans), in the study of Ptatscheck et al. (2018) nematodes comprised 46\% of the sampled animals (crustaceans were not found) and their dispersal rate within 4 weeks was as high as 3,020 individuals $/ \mathrm{m}^{2}$ in a study conducted in central Europe. Other investigations of different locations reported much lower rates of $<5$ individuals $/ \mathrm{m}^{2}$ within 1 year (Nkem et al., 2006: in Antarctica) and 14 individuals $/ \mathrm{m}^{2}$ within 1 month (Vanschoenwinkel et al., 2008a: South Africa during the dry season). An important reason for the large differences in these results is the fundamentally different methods that were used. Thus, while Ptatscheck et al. (2018) collected the organisms using formaldehyde-filled funnels and 5- $\mu \mathrm{m}$ mesh-size filters, Vanschoenwinkel et al. (2008a) collected aeroplankton in windsocks $(100 \mu \mathrm{m})$ and Nkem et al. (2006) analyzed soil samples as well as the contents of open-top chambers and Bundt pan soil traps. Difficulties in comparing the results of studies on wind-drifted organisms were noted by Vanschoenwinkel et al. (2009).

Not all organisms are dispersed equally, with clear limitations as well as different sorting processes described for wind-drifted nematodes, rotifers, cladocerans, copepods and tardigrades (Jenkins, 1995; Cáceres \& Soluk, 2002; Ptatscheck et al., 2018). In the case of nematodes, their form and weight determine the wind energy necessary for their erosion and the transfer range. For example, resting eggs are less effectively transported by wind than are later stages (Cáceres \& Soluk, 2002). Nkem et al. (2006) and Ptatscheck et al. (2018) showed that aerial plankton mainly contains small individuals $(<0.75 \mathrm{~mm})$ and juvenile nematodes with low body weights. Furthermore, anhydrobiosis and the associated weight reduction through water loss enable a more effective wind transfer than possible for hydrated forms (van Gundy, 1965). It is often assumed that the presence of propagules, which are not known from aquatic nematodes, is a prerequisite for the successful wind drift of microscopic aquatic organisms (Panov et al., 2004; Nkem et al., 2006; Incagnone et al., 2015). However, Ptatscheck et al. (2018) found only living stages in 
their collection of wind-drifted organisms and thus argued that the climatic conditions are a crucial determinant of wind drift and that propagules are a feature only of harsher environments.

Additional parameters affecting the wind dispersal of nematodes are wind speed and humidity. More nematodes were collected from the air during periods of higher wind speed (Ptatscheck et al., 2018), suggesting a stronger erosion effect and longer transport distances. The same study showed that dispersal was enhanced by higher humidity, although it is usually assumed that small organisms are mainly dispersed during dry periods because dry surfaces facilitate erosion (Incagnone et al., 2015). Thus, the wind dispersal of nematodes and other microscopic organisms is likely to be strongly seasonal (Ptatscheck et al., 2018).

The distances covered by the aeroplankton range from a few meters (Jenkins \& Underwood, 1998; Vanschoenwinkel et al., 2008a, 2009), to several hundred meters (Maguire, 1963) and up to several dozen kilometers (Carroll \& Viglierchio, 1981). With increasing distance, the number of wind-dispersed nematodes declines (Ptatscheck et al., 2018). However, wind-drifted nematodes can be collected at least $35 \mathrm{~m}$ above the ground, such that transport on a larger scale is plausible (Ptatscheck et al., 2018). While little is known about the colonization success of winddrifted nematodes, it can be assumed that overland dispersal is an important mode of transport for isolated habitats such as tank bromeliads. Studies on the colonization of azoic sediments in streams by aerially transported organisms revealed that, in contrast to other benthic invertebrates such as ostracods or copepods, there was no evidence of the establishment of nematode communities (Williams \& Hynes, 1976; Williams, 1977; Benzie, 1984).

\section{Human-mediated transfer}

Wyatt \& Carlton (2002) pointed out that in discussions of the global distributions of microscopic organisms such as nematodes, not only natural processes but also anthropogenic vectors must be considered, because they are also effective and well documented. In fact, since contact between larger organisms and the sediment often leads to the displacement of meiofauna, nematodes are likely to be common "travel companions" including of humans. Both Waterkeyn et al. (2010b) and Valls et al. (2016) showed that nematodes can be transferred in the mud residue of clothes (here, footwear). Because aquatic nematodes (probably their eggs) in dried sediment are highly viable (Gerlach, 1977), human-mediated transfer is likely to be an important mechanism leading to the dispersal of organisms across different wetland habitats, especially those in highly frequented areas but also sites separated by long distances.

Ships transit lakes, river systems and oceans and with the emptying of their ballast tanks they contribute to the global dispersal of numerous, sometimes invasive, species. Nematodes are the predominant and most diverse meiobenthic taxon collected from the sediments of ballast tanks (Duggan et al., 2005, 2006; Radziejewska et al., 2006). Duggan et al. (2005) identified 48 different freshwater nematode taxa in the tanks of several ships traveling the Great Lakes, which border parts of the USA and Canada. The results of Radziejewska et al. (2006) suggested the transport of $>100,000$ nematodes $(66 \%$ of the collected meiofauna) within the sediment contained in the ballast tank of a bulk carrier. Moreover, depending on the location of sediment uptake, nematode abundance in transported sediments may be even higher.

Finally, even tap water enables the dispersal of nematodes, as these and other meiobenthic organisms (e.g., rotifers, oligochaetes, gastrotrichs, flatworms, microcrustaceans) are present in drinking water distribution systems (Funch et al., 1995; Schreiber et al., 1997; Christensen, 2011; Inkinen et al., 2019). In fact, guideline values for finished water from the Netherlands (in 1993) and North America include the allowance of 0.3 and 2.5 nematodes/l (reviewed by Christensen, 2011). Other studies found up to 156 individuals, belonging to 41 species/l drinking water (reviewed by Artois et al., 2011).

\section{What is left to say?}

The ability to get everywhere

The picture that emerges from this review is that the dispersal pathways of marine and freshwater nematodes are as diverse as the habitats they inhabit, and they include both water but also overland routes (Fig. 1). While active locomotion, whether by 
sediment crawling or by swimming in open waters, enables nematodes to spread over centimeter and meter ranges, passive modes are essential for longerrange dispersals from freshwater and marine environments. Under favorable conditions nematodes can disperse by drift, rafting and zoochory but also as stowaway on ships to reach opposite shores, cross the (dry) ocean and cover distances $>10,000 \mathrm{~km}$. Since the survival rate (e.g., the avoidance of death by starvation, digestion) and recruitment from source habitats decline with increasing time and distance, most distribution probably takes place over smaller ranges, in line with the results of studies based on genetic approaches (Derycke et al., 2007; Bik et al., 2010; Derycke et al., 2013; Hauquier et al., 2017). However, according to the review of Cerca et al. (2018), the presented studies suggests that the meiofauna paradox most likely does not exist because the dispersal of these small organisms is more diverse and effective than often assumed, but not entirely unrestricted (see next section). Finally, although the basic distribution pathways of nematodes have already been demonstrated, the picture is far from complete. For example, the entire spectrum of larger organisms (e.g., crustaceans or even whales) that may transport nematodes by primary or secondary zoochory has yet to be examined in depth and thus offers a wide field for further studies. In addition, most of the studies cited in our review addressed the dispersal of nematodes in marine environments whereas studies from freshwater ecosystems are underrepresented. Indeed, processes that have primarily been described in marine environments, such as rafting, presumably also occur in lakes or streams, but very few studies have examined the importance of water drift for the dispersal of nematodes in lakes (e.g., littoral vs. profundal).

\section{Limitations of dispersal}

This review explored the dispersal modes of nematodes and included comparisons with studies on other meiofaunal organisms to assess the extent of these processes in various environments. However, because microcrustaceans (mainly copepods) and other meiofauna have already been extensively examined in this context, a consideration of all existing studies would have been far beyond the scope of this review, which is why we focused on single examples. The authors of previous studies on the dispersal of marine nematodes (e.g., Palmer, 1988a; Armonies, 1994) concluded that dispersal is primarily passive, with active locomotion playing a more important role in copepods. Our review also shows that nematodes can actively move in water or sediment but as crawlers and swimmers they are less effective than other meiofaunal organisms, in addition to being vulnerable to even low flow velocities of water. While epibenthic organisms such as microcrustaceans or plathelminths immigrate to the water column by active movement, this is the case for only a small percentage of endobenthic nematodes, whose presence in the water column is instead largely due to erosion. Indeed, our review also provides considerable evidence of the limitation of nematode dispersal (Fig. 1) due to (1) organismal morphology, (2) ecological factors, (3) habitat structure and (4) hydrodynamics, which together result in the sorting of species, size classes and feeding types. Morphological characteristics such as body shape determine how fast and how far a nematode can disperse on its own in any direction. This active dispersal is usually triggered by several fundamental ecological factors that act in concert and also determine local population dynamics (Bowler \& Benton, 2005; Matthysen, 2012). For nematodes, these factors include the availability of food resources but also predation, competition, oxygen level and the amount of disturbance. Overland dispersal, which relies on wind and the mobility of larger organisms, is mainly restricted to species of shallow and ephemeral waters as well as littoral zones. In habitats characterized by a high flow velocity, such as streams or shore areas subject to wind, waves and tides, the number of drifting or rafting nematodes originating from the upper substrate layers increases, although additional factors, such as the vertical distribution and habitat structure of the organisms, also play important roles.

If their dispersal is by no means unrestricted, then why are nematodes so successful in entering new habitats? A crucial advantage is the high densities in which nematodes occur. Even if only a small percentage of the nematodes emigrate from the sediment, it is enough to allow a continuous spread of numerous individuals, especially since only a few gravid females can sustain a population. For example, Palmer (1992) showed that $24 \mathrm{~h}$ of nematode immigration by open water dispersal can result in the settling of a larger number of individuals than previously located in the 
home substrate. Further reasons may be found in the subsequent establishment processes described by immigration, which were not considered in this review and have so far hardly been investigated for nematodes in general.

\section{A quick glance at colonization}

Studies that investigated the succession of empty habitats (Table 2) have shown that colonization by nematodes starts immediately, with densities comparable to those of the surrounding habitats reached within a few days. However, for successful dispersal not only the arrival of organisms but also their ability to prevail in the new habitat is crucial. In the case of passive distribution, organisms can reach locations that differ completely in their biotic and abiotic parameters from the source habitat, such that a high degree of adaptability is necessary for survival and reproduction. According to Bongers \& Bongers (1998), nematodes with fast reproduction rates, the ability of parthenogenesis and a tolerance of unfavorable environmental conditions will be successful colonizers. Bacterial (Monhysteridae, Plectidae) and hyphal (Aphelenchoidae) feeding taxa were identified as pioneer organisms in streams, lakes (Duft et al., 2002; Peters et al., 2007; Weber \& Traunspurger, 2016) and ephemeral waters (Ptatscheck \& Traunspurger, 2014; Ptatscheck et al., 2015a), indicative of the important role of food availability during the establishment of nematode communities. Predatory nematodes often occur in higher abundances in more nutritious environments (Michiels \& Traunspurger, 2005b; Schroeder et al., 2012; Kazemi-Dinan et al., 2014; Ptatscheck \& Traunspurger, 2014) and therefore tend to appear during later phases of colonization. Accordingly, in their study of colonization using artificial tree-holes Ptatscheck \& Traunspurger (2014) detected predatory nematode species solely in the treatments with added leaf litter, while Peters et al. (2007) described an increase in species number from 1 to 4 nematode species on artificial hard substrates during the first 10 days of colonization. Not only the availability of food resources but also their exploitation by different nematode species influences the population growth rate and the possibility of becoming established in a habitat, as shown by Ilieva-Makulec (2001) and Gansfort et al. (2018). Furthermore, topdown effects caused by predators or bioturbators can also significantly shape the nematode community (e.g., Weber \& Traunspurger, 2016). These examples show that the sequence in which species immigrate to a habitat and the resulting priority effects, in the form of biological interactions with already established communities (e.g., Incagnone et al., 2015), contribute to defining nematode community structure (Derycke et al., 2013). However, much remains to be learned about the establishment processes of nematodes, as there is still a lack of studies on the succession of new habitats that consider nematodes at the species level.

Further approaches

The studies presented in our review describe the emigration and transport of nematodes and the different spatial levels at which the spread of these organisms occurs. While the short distances covered by active movement can be adequately investigated in laboratory tests, accurately tracing the long-range transfer of nematodes is much more difficult. The migration routes of larger transporting animals (e.g., birds) can be tracked, water flow or wind direction can be taken into account, the effect of hydrodynamics on small organisms in the water column can be calculated and the next possible neighboring populations can be localized. However, none of these approaches has thus far led to a clear understanding of the spread of nematodes and other small organisms. For example, the extent to which nematodes within a river network are connected through dispersal is not known. Studying the genetic diversity of certain nematode species (e.g., Derycke et al., 2013; Ristau et al., 2013; Schenk et al., 2016) can provide insights into the gene flow between species at different locations and thus the extent and range of their dispersal. Furthermore, "sophisticated experimental experiments" are another key for the detailed understanding of meiofauna dispersal processes (Cerca et al., 2018).

\section{Conclusion}

The dispersal modes of nematodes have been investigated in the laboratory and in the field. In some of those studies, collections of nematodes obtained during the transfer phase (e.g., in the water column or on larger organisms) were assessed with respect to a single dispersal mode. In others, the ability of 
nematodes to colonize disturbed or azoic substrates was the focus. Taken together, the results provide further evidence that nematodes are well-equipped pioneer organisms and often one of the first metazoans to establish populations at new, disturbed or even isolated habitats. However, less is known about the importance of long-range dispersal modes, such as zoochory or transport in ship water tanks, for local population structures and even less about the impact of immigrating nematodes on existing or emerging communities. Both translocation and subsequent settlement processes must be taken into account to answer the question whether, for nematodes, getting everywhere means staying everywhere and thus whether nematodes are successful dispersers.

Acknowledgements Open Access funding provided by Projekt DEAL. We would like to thank the anonymous reviewers for their very helpful and constructive remarks.

Open Access This article is licensed under a Creative Commons Attribution 4.0 International License, which permits use, sharing, adaptation, distribution and reproduction in any medium or format, as long as you give appropriate credit to the original author(s) and the source, provide a link to the Creative Commons licence, and indicate if changes were made. The images or other third party material in this article are included in the article's Creative Commons licence, unless indicated otherwise in a credit line to the material. If material is not included in the article's Creative Commons licence and your intended use is not permitted by statutory regulation or exceeds the permitted use, you will need to obtain permission directly from the copyright holder. To view a copy of this licence, visit http://creativecommons.org/licenses/by/4.0/.

\section{References}

Aarnio, K. \& E. Bonsdorff, 1992. Colonization rates and community structure of benthic meiofauna in shallow Baltic Archipelago waters. Aqua Fennica 22: 71-80.

Abdel-Aziz, N. E. \& S. M. Aboul-Ezz, 2004. The structure of zooplankton community in Lake Maryout, Alexandria, Egypt. Egyptian Journal of Aquatic Research 30: 160-170.

Abe, H., T. Komatsu, Y. Kokubu, A. Natheer, E. A. Rothausler, H. Shishido, S. Yoshizawa \& T. Ajisaka, 2013. Invertebrate fauna associated with floating Sargassum horneri (Fucales: Sargassaceae) in the East China Sea. Species Diversity 18: 75-85.

Abebe, E. \& A. Coomans, 1995. Freshwater nematodes of the Galapagos. Hydrobiologia 299: 1-51.

Adams, P. J. M. \& S. Tyler, 1980. Hopping locomotion in a nematode: functional anatomy of the caudal gland apparatus of Theristus caudasaliens sp. n. Journal of Morphology 164: 265-285.
Akasaka, M. \& N. Takamura, 2012. Hydrologic connection between ponds positively affects macrophyte alpha and gamma diversity but negatively affects beta diversity. Ecology 93: 967-973.

Alheit, J. \& W. Scheibel, 1982. Benthic harpacticoids as a food source for fish. Marine Biology 70: 141-147.

Alldredge, A. L. \& J. M. King, 1977. Distribution, abundance, and substrate preferences of demersal reef zooplankton at Lizard Island Lagoon, Great Barrier Reef. Marine Biology 41: 317-333.

Alongi, D. M., D. F. Boesch \& R. J. Diaz, 1983. Colonization of meiobenthos in oil-contaminated subtidal sands in the Lower Chesapeake Bay. Marine Biology 72: 325-335.

Anderson, S. M. \& A. C. Charters, 1982. A fluid dynamics study of seawater flow through Gelidium nudifrons 1. Limnology and Oceanography 27: 399-412.

Andrássy, I., 1978. Fresh-water nematodes from the Himalayas (Nepal). Opuscula Zoologica 15: 3-21.

Apolônio Silva de Oliveira, D., W. Decraemer, T. Moens, G. A. P. Dos Santos \& S. Derycke, 2017. Low genetic but high morphological variation over more than $1000 \mathrm{~km}$ coastline refutes omnipresence of cryptic diversity in marine nematodes. BMC Evolutionary Biology 17: 71.

Armonies, W., 1988a. Active emergence of meiofauna from intertidal sediment. Marine Ecology Progress Series 43: 151-159.

Armonies, W., 1988b. Hydrodynamic factors affecting behaviour of intertidal meiobenthos. Ophelia 28: 183-193.

Armonies, W., 1989. Occurrence of meiofauna in Phaeocystis seafoam. Marine Ecology Progress Series 53: 305-309.

Armonies, W., 1994. Drifting meio- and macrobenthic invertebrates on tidal flats in Königshafen: a review. Helgoländer Meeresuntersuchungen 48: 299-320.

Arroyo, N. L., K. Aarnio \& E. Bonsdorff, 2006. Drifting algae as a means of re-colonizing defaunated sediments in the Baltic Sea. A short-term microcosm study. Hydrobiologia 554: 83-95.

Artois, T., D. Fontaneto, W. D. Hummon, S. J. McInnes, M. A. Todaro, M. V. Sørensen \& A. Zullini, 2011. Ubiquity of microscopic animals? Evidence from the morphological approach in species identification. In Fontaneto, D. \& D. Fontaneto (eds), Biogeography of Microscopic Organisms. Cambridge University Press, Cambridge: 244-283.

Atilla, N., J. W. Fleeger \& C. M. Finelli, 2005. Effects of habitat complexity and hydrodynamics on the abundance and diversity of small invertebrates colonizing artificial substrates. Journal of Marine Research 63: 1151-1172.

Baujard, P. \& B. Martiny, 1994. Transport of nematodes by wind in the peanut cropping area of Senegal, West Africa. Fundamental Applied Nematology 17: 543-550.

Beier, S. \& W. Traunspurger, 2003a. Seasonal distribution of free-living nematodes in the Körsch, a coarse-grained submountain carbonate stream in southwest Germany. Nematology 5: 481-504.

Beier, S. \& W. Traunspurger, 2003b. Seasonal distribution of free-living nematodes in the Krähenbach, a fine-grained submountain carbonate stream in southwest Germany. Nematology 5: 113-136.

Beier, S. \& W. Traunspurger, 2003c. Temporal dynamics of meiofauna communities in two small submountain 
carbonate streams with different grain size. Hydrobiologia 498: 107-131.

Bell, S. S. \& K. M. Sherman, 1980. A field investigation of meiofaunal dispersal: tidal resuspension and implications. Marine Ecology Progress Series 3: 245-249.

Benzie, J. A. H., 1984. The colonisation mechanisms of stream benthos in a tropical river (Menik Ganga: Sri Lanka). Hydrobiologia 111: 171-179.

Bertelsen, R. D., 1997. Active and Passive Settling by Marine Benthic Nematodes. Old Dominion University Libraries, Norfolk.

Bik, H. M., W. K. Thomas, D. H. Lunt \& P. J. D. Lambshead, 2010. Low endemism, continued deep-shallow interchanges, and evidence for cosmopolitan distributions in free-living marine nematodes (order Enoplida). BMC Evolutionary Biology 10: 389.

Billheimer, L. E. \& B. C. Coull, 1988. Bioturbation and recolonization of meiobenthos in juvenile spot (Pisces) feeding pits. Estuarine, Coastal and Shelf Science 27: 335-340.

Boeckner, M. J., J. Sharma \& H. C. Proctor, 2009. Revisiting the meiofauna paradox: dispersal and colonization of nematodes and other meiofaunal organisms in low- and highenergy environments. Hydrobiologia 624: 91-106.

Bongers, T. \& M. Bongers, 1998. Functional diversity of nematodes. Applied Soil Ecology 10: 239-251.

Bonte, D. \& M. Dahirel, 2017. Dispersal: a central and independent trait in life history. Oikos 126: 472-479.

Bonte, D., H. van Dyck, J. M. Bullock, A. Coulon, M. Delgado, M. Gibbs, V. Lehouck, E. Matthysen, K. Mustin, M. Saastamoinen, N. Schtickzelle, V. M. Stevens, S. Vandewoestijne, M. Baguette, K. Barton, T. G. Benton, A. Chaput-Bardy, J. Clobert, C. Dytham, T. Hovestadt, C. M. Meier, S. C. F. Palmer, C. Turlure \& J. M. J. Travis, 2012. Costs of dispersal. Biological Reviews of the Cambridge Philosophical Society 87: 290-312.

Boström, C., A. Törnroos \& E. Bonsdorff, 2010. Invertebrate dispersal and habitat heterogeneity: expression of biological traits in a seagrass landscape. Journal of Experimental Marine Biology and Ecology 390: 106-117.

Boulton, A. J., S. E. Stibbe, N. B. Grimm \& S. G. Fisher, 1991. Invertebrate recolonization of small patches of defaunated hyporheic sediments in a Sonoran Desert Stream. Freshwater Biology 26: 267-277.

Bowler, D. E. \& T. G. Benton, 2005. Causes and consequences of animal dispersal strategies: relating individual behaviour to spatial dynamics. Biological Reviews 80: 205-225.

Brustolin, M. C., M. C. Thomas \& P. C. Lana, 2013. A functional and morphological approach to evaluate the vertical migration of estuarine intertidal nematodes during a tidal cycle. Helgoland Marine Research 67: 83-96.

Burgmer, T., J. Reiss, S. A. Wickham \& H. Hillebrand, 2010. Effects of snail grazers and light on the benthic microbial food web in periphyton communities. Aquatic Microbial Ecology 61: 163-178.

Cáceres, C. E. \& D. A. Soluk, 2002. Blowing in the wind: a field test of overland dispersal and colonization by aquatic invertebrates. Oecologia 131: 402-408.

Cadotte, M. W., 2006. Dispersal and species diversity: a metaanalysis. The American Naturalist 167: 913-924.
Carrara, F., F. Altermatt, I. Rodriguez-Iturbe \& A. Rinaldo, 2012. Dendritic connectivity controls biodiversity patterns in experimental metacommunities. Proceedings of the National Academy of Sciences of the United States of America 109: 5761-5766.

Carroll, J. J. \& D. R. Viglierchio, 1981. On the transport of nematodes by the wind. Journal of Nematology 13: 476-483.

Cerca, J., G. Purschke \& T. H. Struck, 2018. Marine connectivity dynamics: clarifying cosmopolitan distributions of marine interstitial invertebrates and the meiofauna paradox. Marine Biology 165: 2109.

Chan, M. A., K. Moser, J. M. Davis, G. Southam, K. Hughes \& T. Graham, 2005. Desert potholes: ephemeral aquatic microsystems. Aquatic Geochemistry 11: 279-302.

Chandler, G. T. \& J. W. Fleeger, 1983. Meiofaunal colonization of azoic estuarine sediment in Louisiana: mechanisms of dispersal. Journal of Experimental Marine Biology and Ecology 69: 175-188.

Choe, A., S. H. von Reuss, D. Kogan, R. B. Gasser, E. G. Platzer, F. C. Schroeder \& P. W. Sternberg, 2012. Ascaroside signaling is widely conserved among nematodes. Current Biology 22: 772-780.

Christensen, S. C. B., 2011. Assellus aquaticus and Other Invertebrates in Drinking Water Distribution Systems: Occurrence and Influence on Microbial Water Quality. Technical University of Denmark, Department of Environmental Engineering, Kgs Lyngby.

Clifford, H. F., 1972. Drift of invertebrates in an intermittent stream draining marshy terrain of west-central Alberta. Canadian Journal of Zoology 50: 985-991.

Colangelo, M. A. \& V. U. Ceccherelli, 1994. Meiofaunal recolonization of azoic sediment in a Po Delta Lagoon (Sacca di Goro). Bolletino di zoologia 61: 335-342.

Commito, J. A. \& G. Tita, 2002. Differential dispersal rates in an intertidal meiofauna assemblage. Journal of Experimental Marine Biology and Ecology 268: 237-256.

Cook, J. A., J. C. Chubb \& C. J. Veltkamp, 2002. Epibionts of Asellus aquaticus (L.) (Crustacea, Isopoda): an SEM study. Freshwater Biology 39: 423-438.

Corrêa, G. V. V., J. Ingels, Y. V. Valdes, V. G. Fonsêca-Genevois, C. M. R. Farrapeira \& G. A. P. Santos, 2014. Diversity and composition of macro- and meiofaunal carapace epibionts of the hawksbill sea turtle (Eretmochelys imbricata Linnaeus, 1822) in Atlantic waters. Marine Biodiversity 44: 391-401.

Crofton, H. D., 1966. Nematodes. Hutchinson University Library, London.

Cross, R. E. \& M. C. Curran, 2004. Recovery of meiofauna in intertidal feeding pits created by rays. Southeastern Naturalist 3: 219-230.

Crowe, J. H. \& K. A. Madin, 1974. Anhydrobiosis in tardigrades and nematodes. Transactions of the American Microscopical Society 93: 513.

da Fonsêca-Genevois, V., P. J. Somerfield, M. H. B. Neves, R. Coutinho \& T. Moens, 2006. Colonization and early succession on artificial hard substrata by meiofauna. Marine Biology 148: 1039-1050.

de Groote, A., F. Hauquier, A. Vanreusel \& S. Derycke, 2017. Population genetic structure in Sabatieria (Nematoda) reveals intermediary gene flow and admixture between 
distant cold seeps from the Mediterranean Sea. BMC Evolutionary Biology 17: 154.

de Meester, N., S. Derycke \& T. Moens, 2012. Differences in time until dispersal between cryptic species of a marine nematode species complex. PLoS ONE 7: e42674.

de Meester, N., S. Derycke, A. Rigaux \& T. Moens, 2015. Active dispersal is differentially affected by inter- and intraspecific competition in closely related nematode species. Oikos 124: 561-570.

de Meester, N., T. van Daele, J. van Malderen, L. Monteiro, C. van Colen, S. Derycke \& T. Moens, 2018. Active and species-specific dispersal behaviour in a marine nematode cryptic species complex. Marine Ecology Progress Series 600: 71-83.

de Troch, M., L. Vandepitte, M. Raes, E. Suàrez-Morales \& M. Vincx, 2005. A field colonization experiment with meiofauna and seagrass mimics: effect of time, distance and leaf surface area. Marine Biology 148: 73-86.

DePatra, K. D. \& L. A. Levin, 1989. Evidence of the passive deposition of meiofauna into fiddler crab burrows. Journal of Experimental Marine Biology and Ecology 125: 173-192.

Derycke, S., R. van Vynckt, J. Vanoverbeke, M. Vincx \& T. Moens, 2007. Colonization patterns of Nematoda on decomposing algae in the estuarine environment: community assembly and genetic structure of the dominant species Pellioditis marina. Limnology and Oceanography 52: 992-1001.

Derycke, S., T. Remerie, T. Backeljau, A. Vierstraete, J. Vanfleteren, M. Vincx \& T. Moens, 2008. Phylogeography of the Rhabditis (Pellioditis) marina species complex: evidence for long-distance dispersal, and for range expansions and restricted gene flow in the northeast Atlantic. Molecular Ecology 17: 3306-3322.

Derycke, S., T. Backeljau \& T. Moens, 2013. Dispersal and gene flow in free-living marine nematodes. Frontiers in Zoology 10: 1.

Dias, J. D., N. R. Simões, M. Meerhoff, F. A. Lansac-Tôha, L. F. M. Velho \& C. C. Bonecker, 2016. Hydrological dynamics drives zooplankton metacommunity structure in a Neotropical floodplain. Hydrobiologia 781: 109-125.

Dimas-Flores, N., J. Alcocer \& J. Ciros-Pérez, 2008. The structure of the zooplankton assemblages from two neighboring tropical high mountain lakes. Journal of Freshwater Ecology 23: 21-31.

dos Santos, G. A. P., G. V. V. Corrêa, Y. Valdes, D. Apolônio Silva de Oliveira, V. G. Fonsêca-Genevois, A. C. Silva, L. P. Pontes, E. Dolan \& J. Ingels, 2018. Eretmochelys imbricata shells present a dynamic substrate for a facilitative epibiont relationship between macrofauna richness and nematode diversity, structure and function. Journal of Experimental Marine Biology and Ecology 502: 153-163.

Duft, M., K. Fittkau, W. Traunspurger \& S. Fittkau, 2002. Colonization of exclosures in a Costa Rican Stream: effects of macrobenthos on meiobenthos and the nematode community. Journal of Freshwater Ecology 17: 531-541.

Duggan, I. C., C. D. A. van Overdijk, S. A. Bailey, P. T. Jenkins, H. Limén \& H. J. MacIsaac, 2005. Invertebrates associated with residual ballast water and sediments of cargo-carrying ships entering the Great Lakes. Canadian Journal of Fisheries and Aquatic Sciences 62: 2463-2474.
Duggan, I. C., S. A. Bailey, C. D. A. van Overdijk \& H. J. MacIsaac, 2006. Invasion risk of active and diapausing invertebrates from residual ballast in ships entering Chesapeake Bay. Marine Ecology Progress Series 324: 57-66.

Eckman, J. E., 1983. Hydrodynamic processes affecting benthic recruitment1. Limnology and Oceanography 28: 241-257.

Eddy, S., 1927. The plankton of Lake Michigan. Illinois Natural History Survey Bulletin 17: 202-232.

Eisenmann, H., E. I. Meyer \& W. Traunspurger, 1998. Community structure of selected micro- and meiobenthic organisms in sediment chambers from a prealpine river (Necker, Switzerland). In Bretschko, G. (ed.), Advances in River Bottom Ecology. Backhuys, Leiden: 155-162.

Enright, J. T., 1977. Copepods in a hurry: sustained high-speed upward migration1. Limnology and Oceanography 22: $118-125$.

Eskin, R. A. \& M. A. Palmer, 1985. Suspension of marine nematodes in a turbulent tidal creek: species patterns: species patterns. The Biological Bulletin 169: 615-623.

Faust, M. A. \& R. A. Gulledge, 1996. Associations of microalgae and meiofauna in floating detritus at a mangrove island, Twin Cays, Belize. Journal of Experimental Marine Biology and Ecology 197: 159-175.

Fegley, S. R., 1987. Experimental variation of near-bottom current speeds and its effects on depth distribution of sandliving meiofauna. Marine Biology 95: 183-191.

Fegley, S. R., 1988. A comparison of meiofaunal settlement onto the sediment surface and recolonization of defaunated sandy sediment. Journal of Experimental Marine Biology and Ecology 123: 97-113.

Fernandez-Leborans, G., 2001. A review of the species of protozoan epibionts on crustaceans. III. Chonotrich ciliates. Crustaceana 74: 581-607.

Fernandez-Leborans, G. \& M. L. Tato-Porto, 2000a. A review of the species of protozoan epibionts on crustaceans. I. Peritrich ciliates. Crustaceana 73: 643-683.

Fernandez-Leborans, G. \& M. L. Tato-Porto, 2000b. A review of the species of protozoan epibionts on crustaceans. II. Suctorian ciliates. Crustaceana 73: 1205-1237.

Fernando, C. H., 1980. The freshwater zooplankton of Sri Lanka, with a discussion of tropical freshwater zooplankton composition. Internationale Revue der gesamten Hydrobiologie und Hydrographie 65: 85-125.

Fonseca, M. S., J. S. Fisher, J. C. Zieman \& G. W. Thayer, 1982. Influence of the seagrass, Zostera marina L., on current flow. Estuarine, Coastal and Shelf Science 15: 351-364.

Fontaneto, D., 2019. Long-distance passive dispersal in microscopic aquatic animals. Movement Ecology 7: 10.

Frankland, P. F., 1886. The distribution of micro-organisms in air. Proceedings of the Royal Society of London 40: 509-526.

Frisch, D., A. J. Green \& J. Figuerola, 2007. High dispersal capacity of a broad spectrum of aquatic invertebrates via waterbirds. Aquatic Sciences 69: 568-574.

Funch, P., H. Segers \& H. J. Dumont, 1995. Rotifera in tap water in Gent, Belgium. Biologisch Jaarboek - Dodonaea 63: 53-57.

Gallucci, F., M. Steyaert \& T. Moens, 2005. Can field distributions of marine predacious nematodes be explained by sediment constraints on their foraging success? Marine Ecology Progress Series 304: 167-178. 
Gallucci, F., T. Moens, A. Vanreusel \& G. Fonseca, 2008. Active colonisation of disturbed sediments by deep-sea nematodes: evidence for the patch mosaic model. Marine Ecology Progress Series 367: 173-183.

Gansfort, B. \& W. Traunspurger, 2019. Environmental factors and river network position allow prediction of benthic community assemblies: a model of nematode metacommunities. Scientific Reports 9: 601.

Gansfort, B., J. Uthoff \& W. Traunspurger, 2018. Interactions among competing nematode species affect population growth rates. Oecologia 187: 75-84.

Gaston, G. R., 1992. Green-winged teal ingest epibenthic meiofauna. Estuaries 15: 227.

Gaudes, A., S. Sabater, E. Vilalta \& I. Muñoz, 2006. The nematode community in cyanobacterial biofilms in the River Llobregat, Spain. Nematology 8: 909-919.

Gerlach, S. A., 1977. Means of meiofauna dispersal. Mikrofauna Meeresboden 61: 89-103.

Ghosh, R. \& S. W. Emmons, 2008. Episodic swimming behavior in the nematode $C$. elegans. The Journal of Experimental Biology 211: 3703-3711.

Giere, O., 2009. Meiobenthology: The Microscopic Motile Fauna of Aquatic Sediments, 2nd ed. Springer, Berlin.

Gray, J. \& H. W. Lissmann, 1964. The locomotion of nematodes. Journal of Experimental Biology 41: 135-154.

Green, A. J. \& J. Figuerola, 2005. Recent advances in the study of long-distance dispersal of aquatic invertebrates via birds. Diversity and Distribution 11: 149-156.

Green, A. J., K. M. Jenkins, D. Bell, P. J. Morris \& R. T. Kingsford, 2008. The potential role of waterbirds in dispersing invertebrates and plants in arid Australia. Freshwater Biology 53(2): 380-392.

Grönroos, M., J. Heino, T. Siqueira, V. L. Landeiro, J. Kotanen \& L. M. Bini, 2013. Metacommunity structuring in stream networks: roles of dispersal mode, distance type, and regional environmental context. Ecology and Evolution 3: 4473-4487.

Guilini, K., T. Soltwedel, D. van Oevelen \& A. Vanreusel, 2011. Deep-sea nematodes actively colonise sediments, irrespective of the presence of a pulse of organic matter: results from an in situ experiment. PLoS ONE 6: e18912.

Gusakov, V. A., V. G. Gagarin \& E. S. Gusev, 2011. The first results of meiobenthos study in the Cái River (Central Vietnam). Inland Water Biology 4: 357-366.

Hagerman, G. M. \& R. M. Rieger, 1981. Dispersal of benthic meiofauna by wave and current action in Bogue Sound, North Carolina, USA. Marine Ecology 2: 245-270.

Hapca, S., P. Budha, I. Young \& J. Crawford, 2007. Movement of the nematode, Phasmarhabditis hermaphrodita, in a structurally heterogeneous environment. Nematology 9: 731-738.

Hauquier, F., L. Ballesteros-Redondo, J. Gutt \& A. Vanreusel, 2016. Community dynamics of nematodes after Larsen IceShelf collapse in the eastern Antarctic Peninsula. Ecology and Evolution 6: 305-317.

Hauquier, F., F. Leliaert, A. Rigaux, S. Derycke \& A. Vanreusel, 2017. Distinct genetic differentiation and species diversification within two marine nematodes with different habitat preference in Antarctic sediments. BMC Evolutionary Biology 17: 120.
Hendelberg, M. \& P. Jensen, 1993. Vertical distribution of the nematode fauna in a coastal sediment influenced by seasonal hypoxia in the bottom water. Ophelia 37: 83-94.

Hessen, D. O., T. C. Jensen \& B. Walseng, 2019. Zooplankton diversity and dispersal by birds; insights from different geographical scales. Frontiers in Ecology and Evolution 7: 1425.

Hicks, G. R. F., 1988. Sediment rafting: a novel mechanism for the small-scale dispersal of intertidal estuarine meiofauna. Marine Ecology Progress Series 48: 69-80.

Highsmith, R. C., 1985. Floating and algal rafting as potential dispersal mechanisms in brooding invertebrates. Marine Ecology Progress Series 25: 169-179.

Hofsten, A. V., D. Kahan, R. Katznelson \& T. Bar-El, 1983. Digestion of free-living nematodes fed to fish. Journal of Fish Biology 23: 419-428.

Howeth, J. G. \& M. A. Leibold, 2010. Species dispersal rates alter diversity and ecosystem stability in pond metacommunities. Ecology 91: 2727-2741.

Ilieva-Makulec, K., 2001. A comparative study of the life strategies of two bacterial-feeding nematodes under laboratory conditions. II. Influence of the initial food level on the population dynamics of Acrobeloides nanus (de Man 1880) Anderson 1968 and Dolichorhabditis dolichura (Schneider 1866) Andrássy 1983. Polish Journal of Ecology 49(2): 137-144.

Incagnone, G., F. Marrone, R. Barone, L. Robba \& L. NaselliFlores, 2015. How do freshwater organisms cross the "dry ocean"? A review on passive dispersal and colonization processes with a special focus on temporary ponds. Hydrobiologia 750: 103-123.

Ingels, J., Y. Valdes, L. P. Pontes, A. C. Silva, P. F. Neres, G. V. V. Corrêa, I. Silver-Gorges, M. M. P. B. Fuentes, A. Gillis, L. Hooper, M. Ware, C. O'Reilly, Q. Bergman, J. Danyuk, S. Sanchez Zarate, L. I. Acevedo Natale \& G. A. P. dos Santos, 2020. Meiofauna life on loggerhead sea turtles-diversely structured abundance and biodiversity hotspots that challenge the meiofauna paradox. Diversity 12: 203.

Ingolfsson, A., 1995. Floating clumps of seaweed around Iceland: natural microcosms and a means of dispersal for shore fauna. Marine Biology 122: 13-21.

Inkinen, J., B. Jayaprakash, S. Siponen, A.-M. Hokajärvi, A. Pursiainen, J. Ikonen, I. Ryzhikov, M. Täubel, A. Kauppinen, J. Paananen, I. T. Miettinen, E. Torvinen, M. Kolehmainen \& T. Pitkänen, 2019. Active eukaryotes in drinking water distribution systems of ground and surface waterworks. Microbiome 7: 99.

Jenkins, D. G., 1995. Dispersal-limited zooplankton distribution and community composition in new ponds. Hydrobiologia 313-314: 15-20.

Jenkins, D. G. \& M. O. Underwood, 1998. Zooplankton may not disperse readily in wind, rain, or waterfowl. Hydrobiologia 387(388): 15-21.

Jenkins, D. G., C. R. Brescacin, C. V. Duxbury, J. A. Elliott, J. A. Evans, K. R. Grablow, M. Hillegass, B. N. Lyon, G. A. Metzger, M. L. Olandese, D. Pepe, G. A. Silvers, H. N. Suresch, T. N. Thompson, C. M. Trexler, G. E. Williams, N. C. Williams \& S. E. Williams, 2007. Does size matter for dispersal distance? Global Ecology and Biogeography 16: 415-425. 
Jensen, P., 1981. Phyto-chemical sensitivity and swimming behaviour of the free-living marine nematode Chromadorita tenuis. Marine Ecology 4: 203-206.

Kappes, H., O. Tackenberg \& P. Haase, 2014. Differences in dispersal- and colonization-related traits between taxa from the freshwater and the terrestrial realm. Aquatic Ecology 48: 73-83.

Kärnä, O.-M., M. Grönroos, H. Antikainen, J. Hjort, J. Ilmonen, L. Paasivirta \& J. Heino, 2015. Inferring the effects of potential dispersal routes on the metacommunity structure of stream insects: as the crow flies, as the fish swims or as the fox runs? Journal of Animal Ecology 84: 1342-1353.

Kazemi-Dinan, A., F. Schroeder, L. Peters, N. Majdi \& W. Traunspurger, 2014. The effect of trophic state and depth on periphytic nematode communities in lakes. Limnologica 44: 49-57.

Khalifa, N., K. A. El-Damhogy, M. Reda Fishar, A. M. Nasef \& M. H. Hegab, 2015. Vertical distribution of zooplankton in Lake Nasser. The Egyptian Journal of Aquatic Research 41: 177-185.

Kitching, R. L., 2000. Food Webs and Container Habitats: The Natural History and Ecology of Phytotelmata. University Press, Cambridge.

Kreuzinger-Janik, B., M. Brinke, W. Traunspurger \& N. Majdi, 2017. Life history traits of the free-living nematode, Plectus acuminatus Bastian, 1865, and responses to cadmium exposure. Nematology 19: 645-654.

Kreuzinger-Janik, B., S. Kruscha, N. Majdi \& W. Traunspurger, 2018. Flatworms like it round: nematode consumption by Planaria torva (Müller 1774) and Polycelis tenuis (Ijima 1884). Hydrobiologia 819: 231-242.

Leduc, D. \& A. A. Rowden, 2018. Nematode communities in sediments of the Kermadec Trench, Southwest Pacific Ocean. Deep Sea Research Part I: Oceanographic Research Papers 134: 23-31.

Lee, H., D. Gerdes, S. Vanhove \& M. Vincx, 2001a. Meiofauna response to iceberg disturbance on the Antarctic Continental Shelf at Kapp Norvegia (Weddell Sea). Polar Biology 24: 926-933.

Lee, H., S. Vanhove, L. Peck \& M. Vincx, 2001b. Recolonisation of meiofauna after catastrophic iceberg scouring in shallow Antarctic sediments. Polar Biology 24: 918-925.

Leibold, M. A., M. Holyoak, N. Mouquet, P. Amarasekare, J. M. Chase, M. F. Hoopes, R. D. Holt, J. B. Shurin, R. Law, D. Tilman, M. Loreau \& A. Gonzalez, 2004. The metacommunity concept: a framework for multi-scale community ecology. Ecology Letters 7: 601-613.

Lins, L., A. Vanreusel, J. van Campenhout \& J. Ingels, 2013. Selective settlement of deep-sea canyon nematodes after resuspension - an experimental approach. Journal of Experimental Marine Biology and Ecology 441: 110-116.

Liston, S. E., 2006. Interactions between nutrient availability and hydroperiod shape macroinvertebrate communities in Florida Everglades marshes. Hydrobiologia 569: 343-357.

Liston, S. E., S. Newman \& J. C. Trexler, 2008. Macroinvertebrate community response to eutrophication in an oligotrophic wetland: an in situ mesocosm experiment. Wetlands 28: 686-694.

Luckenbach, M. W., 1986. Sediment stability around animal tubes: the roles of hydrodynamic processes and biotic activity1. Limnology and Oceanography 31: 779-787.
Luschi, P., G. C. Hays \& F. Papi, 2003. A review of longdistance movements by marine turtles, and the possible role of ocean currents. Oikos 103: 293-302.

Macfarlane, C. B. A., D. Drolet, M. A. Barbeau, D. J. Hamilton \& J. Ollerhead, 2013. Dispersal of marine benthic invertebrates through ice rafting. Ecology 94: 250-256.

Maguire, B., 1959. Passive overland transport of small aquatic organisms. Ecology 40: 312.

Maguire, B., 1963. The passive dispersal of small aquatic organisms and their colonization of isolated bodies of water. Ecological Monographs 33: 161-185.

Matthiessen, B., E. Mielke \& U. Sommer, 2010. Dispersal decreases diversity in heterogeneous metacommunities by enhancing regional competition. Ecology 91: 2022-2033.

Matthysen, E., 2012. Multicausality of dispersal: a review. In Clobert, J., M. Baguette, T. G. Benton \& J. M. Bullock (eds), Dispersal Ecology and Evolution. Oxford University Press, Oxford: 3-18.

Mayer, M. G. \& R. J. Sommer, 2011. Natural variation in Pristionchus pacificus dauer formation reveals cross-preference rather than self-preference of nematode dauer pheromones. Proceedings of Biological Sciences 278: 2784-2790.

McSorley, R., 2003. Adaptions of nematodes to environmental extremes. Florida Entomologist 86: 138-142.

Mevenkamp, L., J. van Campenhout \& A. Vanreusel, 2016. Experimental evidence for selective settlement of meiofauna from two distinct environments after sediment suspension. Journal of Experimental Marine Biology and Ecology 474: 195-203.

Michiels, I. \& W. Traunspurger, 2005a. Benthic community patterns and the composition of feeding types and reproductive modes in freshwater nematodes. Nematology 7: 21-36.

Michiels, I. C. \& W. Traunspurger, 2005b. Impact of resource availability on species composition and diversity in freshwater nematodes. Oecologia 142: 98-103.

Micoletzky, H., 1922. Freilebende Nematoden aus den treibenden Tangen der Sargassosee. Mitteilungen des Hamburger Zoologischen Museums und Institutes 39: $1-11$.

Moens, T., U. Braeckman, S. Derycke, G. Fonseca, F. Gallucci, R. Gingold, K. Guilini, J. Ingels, D. Leduc, J. Vanaverbeke, C. van Colen, A. Vanreusel \& M. Vincx, 2013. 3. Ecology of free-living marine nematodes. In Schmidt-Rhaesa, A. (ed.), Nematoda. De Gruyter, Berlin.

Mott, J. B. \& A. D. Harrison, 1983. Nematodes from river drift and surface drinking water supplies in southern Ontario. Hydrobiologia 102: 27-38.

Muschiol, D. \& W. Traunspurger, 2007. Life cycle and calculation of the intrinsic rate of natural increase of two bacterivorous nematodes, Panagrolaimus sp. and Poikilolaimus sp. from chemoautotrophic Movile Cave, Romania. Nematology 9: 271-284.

Muschiol, D. \& W. Traunspurger, 2009. Life at the extreme: meiofauna from three unexplored lakes in the caldera of the Cerro Azul Volcano, Galápagos Islands, Ecuador. Aquatic Ecology 43: 235-248.

Muschiol, D., M. Marković, I. Threis \& W. Traunspurger, 2008. Predator-prey relationship between the cyclopoid copepod 
Diacyclops bicuspidatus and a free-living bacterivorous nematode. Nematology 10: 55-62.

Muschiol, D., O. Giere \& W. Traunspurger, 2015. Population dynamics of a cavernicolous nematode community in a chemoautotrophic groundwater system. Limnology and Oceanography 60: 127-135.

Nathan, R., 2001. The challenges of studying dispersal. Trends in Ecology and Evolution 16: 481-483.

Neira, C., I. King, G. Mendoza, J. Sellanes, P. de Ley \& L. A. Levin, 2013. Nematode community structure along a central Chile margin transect influenced by the oxygen minimum zone. Deep Sea Research Part I: Oceanographic Research Papers 78: 1-15.

Nkem, J. N., D. H. Wall, R. A. Virginia, J. E. Barrett, E. J. Broos, D. L. Porazinska \& B. J. Adams, 2006. Wind dispersal of soil invertebrates in the McMurdo Dry Valleys, Antarctica. Polar Biology 29: 346-352.

Norkko, J., E. Bonsdorff \& A. Norkko, 2000. Drifting algal mats as an alternative habitat for benthic invertebrates. Journal of Experimental Marine Biology and Ecology 248: 79-104.

Nowell, A. R. M. \& P. A. Jumars, 1984. Flow environments of aquatic benthos. Annual Review of Ecology and Systematics 15: 303-328.

Ólafsson, E., 2003. Do macrofauna structure meiofauna assemblages in marine soft bottoms? Vie Milieu 53(4): 249-265.

Olafsson, E. \& C. G. Moore, 1990. Control of meiobenthic abundance by macroepifauna in a subtidal muddy habitat. Marine Ecology Progress Series 65: 241-249.

Ólafsson, E., K. Aarnio, E. Bonsdorff \& N. L. Arroyo, 2013. Fauna of the green alga Cladophora glomerata in the Baltic Sea: density, diversity, and algal decomposition stage. Marine Biology 160: 2353-2362.

Palmer, M. A., 1984. Invertebrate drift: behavioral experiments with intertidal meiobenthos $\uparrow$. Marine Behaviour and Physiology 10: 235-253.

Palmer, M. A., 1986. Hydrodynamics and structure: interactive effects on meiofauna dispersal. Journal of Experimental Marine Biology and Ecology 104: 53-68.

Palmer, M. A., 1988a. Dispersal of marine meiofauna: a review and conceptual model explaining passive transport and active emergence with implications for recruitment. Marine Ecology Progress Series 48: 81-91.

Palmer, M. A., 1988b. Epibenthic predators and marine meiofauna: separating predation, disturbance, and hydrodynamic effects. Ecology 69: 1251-1259.

Palmer, M. A., 1990. Understanding the movement dynamics of a stream-dwelling meiofauna community using marine analogs. Stygologia 5: 67-74.

Palmer, M. A., 1992. Incorporating lotic meiofauna into our understanding of faunal transport processes. Limnology and Oceanography 37: 329-341.

Palmer, M. A. \& G. Gust, 1985. Dispersal of meiofauna in a turbulent tidal creek. Journal of Marine Research 43: 179-210.

Palmer, M. A. \& R. M. Molloy, 1986. Water flow and the vertical distribution of meiofauna: a flume experiment. Estuaries 9: 225.
Palmer, M. A., A. E. Bely \& K. E. Berg, 1992. Response of invertebrates to lotic disturbance: a test of the hyporheic refuge hypothesis. Oecologia 89: 182-194.

Panov, V. E., P. I. Krylov \& N. Riccardi, 2004. Role of diapause in dispersal and invasion success by aquatic invertebrates. Journal of Limnology 63: 56.

Peters, L. \& W. Traunspurger, 2012. Temporal patterns in macrograzer effects on epilithic algae and meiofauna: a comparative approach to test for single species and whole grazer community effects. Aquatic Sciences 74: 229-240.

Peters, L., M. A. Wetzel, W. Traunspurger \& K.-O. Rothhaupt, 2007. Epilithic communities in a lake littoral zone: the role of water-column transport and habitat development for dispersal and colonization of meiofauna. Journal of the North American Benthological Society 26: 232-243.

Petsch, D. K., G. D. Pinha \& A. M. Takeda, 2017. Dispersal mode and flooding regime as drivers of benthic metacommunity structure in a Neotropical floodplain. Hydrobiologia 788: 131-141.

Phillips, R. C., 1958. Floating communities of algae in a North Carolina pond. Ecology 39: 765-766.

Phillips, R. C., 1963. Ecology of floating algal communities in Florida. Quarterly Journal of the Florida Academy of Sciences 26: 329-334.

Pinder, A. M., S. A. Halse, R. J. Shiel \& J. M. McRae, 2000. Granite outcrop pools in south-western Australia: foci of diversification and refugia for aquatic invertebrates. Journal of Royal Society of Western Australia 83: 117-129.

Platt, H. M., 1977. Vertical and horizontal distribution of freeliving marine nematodes from Strangford Lough, Northern Ireland. Cahiers de Biologie Marine 18: 261-273.

Portnova, D., 2009. Free-living nematodes from the deep-sea Håkon Mosby Mud Volcano, including the description of two new and three known species. Zootaxa 2096: 197-213.

Portnova, D., V. Mokievsky \& T. Soltwedel, 2011. Nematode species distribution patterns at the Håkon Mosby Mud Volcano (Norwegian Sea). Marine Ecology 32: 24-41.

Ptatscheck, C. \& W. Traunspurger, 2014. The meiofauna of artificial water-filled tree holes: colonization and bottomup effects. Aquatic Ecology 48: 285-295.

Ptatscheck, C., B. Dümmer \& W. Traunspurger, 2015a. Nematode colonisation of artificial water-filled tree holes. Nematology 17: 911-921.

Ptatscheck, C., B. Kreuzinger-Janik, H. Putzki \& W. Traunspurger, 2015b. Insights into the importance of nematode prey for chironomid larvae. Hydrobiologia 757: 143-153.

Ptatscheck, C., B. Gansfort \& W. Traunspurger, 2018. The extent of wind-mediated dispersal of small metazoans, focusing nematodes. Scientific Reports 8: 6814.

Radziejewska, T., P. Gruszka \& J. Rokicka-Praxmajer, 2006. A home away from home: a meiobenthic assemblage in a ship's ballast water tank sediment. Oceanologia 48: 259-265.

Ramot, D., B. E. Johnson, T. L. Berry, L. Carnell \& M. B. Goodman, 2008. The Parallel Worm Tracker: a platform for measuring average speed and drug-induced paralysis in nematodes. PLoS ONE 3: e2208.

Riess, W., O. Giere, O. Kohls \& S. M. Sarbu, 1999. Anoxic thermomineral cave waters and bacterial mats as habitat for freshwater nematodes. Aquatic Microbial Ecology 18: 157-164. 
Ristau, K. \& W. Traunspurger, 2011. Relation between nematode communities and trophic state in southern Swedish lakes. Hydrobiologia 663: 121-133.

Ristau, K., S. Steinfartz \& W. Traunspurger, 2013. First evidence of cryptic species diversity and significant population structure in a widespread freshwater nematode morphospecies (Tobrilus gracilis). Molecular Ecology 22: 4562-4575.

Robaina, R. R., R. M. de Souza, V. M. Gomes, D. O. Cardoso, A. M. Almeida \& L. S. A. Gonçalves, 2015. Nematode trophic structure in phytotelmata of Canistropsis billbergioides and Nidularium procerum (Bromeliaceae) in the Atlantic Forest - variability in relation to climate variables and plant architecture. Nematoda. https://doi.org/10.4322/ nematoda.01615.

Robinson, A. F., 1994. Movement of five nematode species through sand subjected to natural temperature gradient fluctuations. Journal of Nematology 26: 46-58.

Rodríguez, J. G., 2004. Intertidal water column meiofauna in relation to wave intensity on an exposed beach. Scientia Marina 68: 181-187.

Ronce, O., 2007. How does it feel to be like a rolling stone? Ten questions about dispersal evolution. Annual Review of Ecology, Evolution, and Systematics 38: 231-253.

Sazima, I. \& C. Zamprogno, 1985. Use of water hyacinths as shelter, foraging place, and transport by young piranhas, Serrasalmus spilopleura. Environmental Biology of Fishes 12: 237-240.

Schabetsberger, R., G. Drozdowski, E. Rott, R. Lenzenweger, C. D. Jersabek, F. Fiers, W. Traunspurger, N. Reiff, F. Stoch, A. A. Kotov, K. Martens, H. Schatz \& R. Kaiser, 2009. Losing the bounty? Investigating species richness in isolated freshwater ecosystems of Oceania. Pacific Science 63: $153-179$.

Schabetsberger, R., R. Kaiser, E. Rott, R. Lenzenweger, W. Traunspurger, A. A. Kotov, F. Fiers, S. Gaviria, C. Meisch, S. Mahunka, R. D. Campbell, E. Razafindranaivo \& M. Sztatecsny, 2013. On the brink - investigating biodiversity in endangered crater lakes of the Amber Mountains National Park (Madagascar). Aquatic Conservation: Marine and Freshwater Ecosystems 23: 316-331.

Schejter, L., M. Escolar \& C. Bremec, 2011. Variability in epibiont colonization of shells of Fusitriton magellanicus (Gastropoda) on the Argentinean Shelf. Journal of the Marine Biological Association of the United Kingdom 91: 897-906.

Schenk, J., W. Traunspurger \& K. Ristau, 2016. Genetic diversity of widespread moss-dwelling nematode species in German beech forests. European Journal of Soil Biology 74: $23-31$.

Schiemer, F., A. Duncan \& R. Z. Klekowski, 1980. A bioenergetic study of a benthic nematode, Plectus palustris de man 1880, throughout its life cycle: II. Growth, fecundity and energy budgets at different densities of bacterial food and general ecological considerations. Oecologia 44: 205-212.

Schlägel, U. E., V. Grimm, N. Blaum, P. Colangeli, M. Dammhahn, J. A. Eccard, S. L. Hausmann, A. Herde, H. Hofer, J. Joshi, S. Kramer-Schadt, M. Litwin, S. D. Lozada-Gobilard, M. E. H. Müller, T. Müller, R. Nathan, J. S. Petermann, K. Pirhofer-Walzl, V. Radchuk, M. C. Rillig, M. Roeleke, M. Schäfer, C. Scherer, G.
Schiro, C. Scholz, L. Teckentrup, R. Tiedemann, W. Ullmann, C. C. Voigt, G. Weithoff \& F. Jeltsch, 2020. Movement-mediated community assembly and coexistence. Biological Reviews 86: 342.

Schlechtriem, C., U. Focken \& K. Becker, 2005. Digestion and assimilation of the free-living nematode Panagrellus redivivus fed to first feeding coregonid larvae: evidence from histological and isotopic studies. Journal of the World Aquaculture Society 36: 24-31.

Schmid-Araya, J. M., 1997. Temporal and spatial dynamics of meiofaunal assemblages in the hyporheic interstitial of a gravel stream. In Fournier, F., J. Gibert \& J. Mathieu (eds), Groundwater/Surface Water Ecotones: Biological and Hydrological Interactions and Management Options., International Hydrology Series Cambridge University Press, Cambridge: 29-36.

Schmid-Araya, J. M., 2000. Invertebrate recolonization patterns in the hyporheic zone of a gravel stream. Limnology and Oceanography 45: 1000-1005.

Scholz, D. S., L. L. Matthews \& R. J. Feller, 1991. Detecting selective digestion of meiobenthic prey by juvenile spot Leiostomus xanthurus (Pisces) using immunoassays. Marine Ecology Progress Series 72: 59-67.

Schratzberger, M., P. Whomersley, K. Warr, S. G. Bolam \& H. L. Rees, 2004. Colonisation of various types of sediment by estuarine nematodes via lateral infaunal migration: a laboratory study. Marine Biology 145: 69-78.

Schratzberger, M., K. Warr \& S. I. Rogers, 2007. Functional diversity of nematode communities in the southwestern North Sea. Marine Environmental Research 63: 368-389.

Schreiber, H., D. Schoenen \& W. Traunspurger, 1997. Invertebrate colonization of granular activated carbon filters. Water Research 31: 743-748.

Schroeder, F., D. Muschiol \& W. Traunspurger, 2010. Fluctuating food availability may permit coexistence in bacterivorous nematodes. Fundamental and Applied Limnology/Archiv für Hydrobiologie 178: 59-66.

Schroeder, F., L. Peters \& W. Traunspurger, 2012. Temporal variations in epilithic nematode assemblages in lakes of different productivities. Fundamental and Applied Limnology/Archiv für Hydrobiologie 181: 143-157.

Schroeder, F., D. Kathöfer, W. Traunspurger \& L. Peters, 2013. Grazing effects on nematodes and other components of the periphyton at three depths in Lake Erken. Freshwater Science 32: 1088-1100.

Schünemann, H. \& I. Werner, 2005. Seasonal variations in distribution patterns of sympagic meiofauna in Arctic pack ice. Marine Biology 146: 1091-1102.

Shanks, A. L. \& E. W. Edmondson, 1990. The vertical flux of metazoans (holoplankton, meiofauna, and larval invertebrates) due to their association with marine snow. Limnology and Oceanography 35: 455-463.

Shanks, A. L. \& K. Walters, 1997. Holoplankton, meroplankton, and meiofauna associated with marine snow. Marine Ecology Progress Series 156: 75-86.

Sherman, K. M. \& B. C. Coull, 1980. The response of meiofauna to sediment disturbance. Journal of Experimental Marine Biology and Ecology 46: 59-71.

Sherman, K. M., J. A. Reidenauer, D. Thistle \& D. Meeter, 1983. Role of a natural disturbance in an assemblage of marine 
free-living nematodes. Marine Ecology Progress Series 11: 23-30.

Sibert, J. R., 1981. Intertidal hyperbenthic populations in the Nanaimo Estuary. Marine Biology 64: 259-265.

Smith, F. \& A. V. Brown, 2006. Effects of flow on meiofauna colonization in artificial streams and reference sites within the Illinois River, Arkansas. Hydrobiologia 571: 169-180.

Soetaert, K., A. Muthumbi \& C. Heip, 2002. Size and shape of ocean margin nematodes: morphological diversity and depth-related patterns. Marine Ecology Progress Series 242: 179-193.

Steyaert, M., P. M. J. Herman, T. Moens, J. Widdows \& M. Vincx, 2001. Tidal migration of nematodes on an estuarine tidal flat (the Molenplaat, Schelde Estuary, SW Netherlands). Marine Ecology Progress Series 224: 299-304.

Strommer, J. L. \& L. A. Smock, 1989. Vertical distribution and abundance of invertebrates within the sandy substrate of a low-gradient headwater stream. Freshwater Biology 22: 263-274.

Sudhaus, W., 2018. Dispersion of nematodes (Rhabditida) in the guts of slugs and snails. Soil Organisms. https://doi.org/10. 25674/4jp6-0v30.

Sun, B. \& J. W. Fleeger, 1994. Field experiments on the colonization of meiofauna into sediment depressions. Marine Ecology Progress Series 110: 167.

Suren, A., 1990. Microfauna associated with algal mats in melt ponds of the Ross Ice Shelf. Polar Biology 10: 329-335.

Tahseen, Q., 2012. Nematodes in aquatic environments: adaptations and survival strategies. Biodiversity Journal 3(1): $13-40$.

Tchesunov, A. V., 2015. Free-living nematode species (Nematoda) dwelling in hydrothermal sites of the North MidAtlantic Ridge. Helgoland Marine Research 69: 343-384.

Teiwes, M., M. Bergtold \& W. Traunspurger, 2007. Factors influencing the vertical distribution of nematodes in sediments. Journal of Freshwater Ecology 22: 429-439.

Thiel, M. \& L. Gutow, 2004a. The ecology of rafting in the marine environment. I. The floating substrata. In Gibson, R., R. Atkinson \& J. Gordon (eds), Oceanography and Marine Biology. Oceanography and Marine Biology - An Annual Review. CRC Press, Boca Raton: 181-263.

Thiel, M. \& L. Gutow, 2004b. The ecology of rafting in the marine environment. II. The rafting organisms and community. In Gibson, R., R. Atkinson \& J. Gordon (eds), Oceanography and Marine Biology Oceanography and Marine Biology - An Annual Review. CRC Press, Boca Raton: 279-418.

Thistle, D. \& K. M. Sherman, 1985. The nematode fauna of a deep-sea site exposed to strong near-bottom currents. Deep Sea Research Part A: Oceanographic Research Papers 32: 1077-1088.

Thomas, M. C. \& P. C. Lana, 2011. A new look into the smallscale dispersal of free-living marine nematodes. Zoologia (Curitiba) 28: 449-456.

Tita, G., M. Vincx \& G. Desrosiers, 1999. Size spectra, body width and morphotypes of intertidal nematodes: an ecological interpretation. Journal of the Marine Biological Association of the United Kingdom 79: 1007-1015.

Tonkin, J. D., F. Altermatt, D. S. Finn, J. Heino, J. D. Olden, S. U. Pauls \& D. A. Lytle, 2018. The role of dispersal in river network metacommunities: patterns, processes, and pathways. Freshwater Biology 63: 141-163.

Tornero, I., D. Boix, S. Bagella, C. Pinto-Cruz, M. C. Caria, A. Belo, A. Lumbreras, J. Sala, J. Compte \& S. Gascón, 2018. Dispersal mode and spatial extent influence distance-decay patterns in pond metacommunities. PLoS ONE 13: e0203119.

Traunspurger, W., 1995. Autecology of Rhabdolaimus terrestris De Man - a dominant freshwater nematode in an oligotrophic lake. Nematology 41: 603-616.

Traunspurger, W., 1996a. Distribution of benthic nematodes in the littoral of an oligotrophic lake (Königssee, National Park Berchtesgaden, FRG). Archiv für Hydrobiologie 135: 393-412.

Traunspurger, W., 1996b. Distribution of benthic nematodes in the littoriprofundal and profundal of an oligotrophic lake (Königssee, National Park Berchtesgaden, FRG). Archiv für Hydrobiologie 135: 557-575.

Traunspurger, W., 1997. Distribution, seasonal occurrence and vertical pattern of Tobrilus gracilis (Bastian, 1865) and T. Medius (Schneider, 1916). Nematology 43: 59-81.

Traunspurger, W., 2000. The biology and ecology of lotic nematodes. Freshwater Biology 44: 29-45.

Traunspurger, W. \& C. Drews, 1996. Vertical distribution of benthic nematodes in an oligotrophic lake: seasonality, species and age segregation. Hydrobiologia 331: 33-42.

Traunspurger, W., M. Bergtold, A. Ettemeyer \& W. Goedkoop, 2006. Effects of copepods and chironomids on the abundance and vertical distribution of nematodes in a freshwater sediment. Journal of Freshwater Ecology 21: 81-90.

Traunspurger, W., S. Höss, A. Witthöft-Mühlmann, M. Wessels \& H. Güde, 2012. Meiobenthic community patterns of oligotrophic and deep Lake Constance in relation to water depth and nutrients. Fundamental and Applied Limnology/ Archiv für Hydrobiologie 180: 233-248.

Traunspurger, W., I. Threis \& N. Majdi, 2015. Vertical and temporal distribution of free-living nematodes dwelling in two sandy-bed streams fed by helocrene springs. Nematology 17: 923-940.

Tsalolikhin, S., 2014. To the fauna of the free-living nematodes (Nematoda) of high-mountain water bodies of the Western Himalayas and the Pamir. Zoosystematica Rossica 23: 178-187.

Turpenniemi, T. A. \& H. Hyvärinen, 1996. Structure and role of the renette cell and caudal glands in the nematode Sphaerolaimus gracilis (Monhysterida). Journal of Nematology 28: 318-327.

Ullberg, J., 2004. Dispersal in Free-Living, Marine, Benthic Nematodes: Passive or Active Processes?. Zoologiska institutionen, Univ, Stockholm.

Ullberg, J. \& E. Ólafsson, 2003a. Effects of biological disturbance by Monoporeia affinis (Amphipoda) on small-scale migration of marine nematodes in low-energy soft sediments. Marine Biology 143: 867-874.

Ullberg, J. \& E. Ólafsson, 2003b. Free-living marine nematodes actively choose habitat when descending from the water column. Marine Ecology Progress Series 260: 141-149.

Valanko, S., J. Norkko \& A. Norkko, 2015. Does stability in local community composition depend on temporal variation in rates of dispersal and connectivity? Journal of Sea Research 98: 24-32. 
Valls, L., A. Castillo-Escrivà, F. Mesquita-Joanes \& X. Armengol, 2016. Human-mediated dispersal of aquatic invertebrates with waterproof footwear. Ambio 45: 99-109.

van Gaever, S., L. Moodley, D. de Beer \& A. Vanreusel, 2006. Meiobenthos at the Arctic Håkon Mosby Mud Volcano, with a parental-caring nematode thriving in sulphide-rich sediments. Marine Ecology Progress Series 321: 143-155.

van Gundy, S. D., 1965. Factors in survival of nematodes. Annual Review of Phytopathology 3: 43-68.

van Leeuwen, C. H. A., Á. Lovas-Kiss, M. Ovegård \& A. J. Green, 2017. Great cormorants reveal overlooked secondary dispersal of plants and invertebrates by piscivorous waterbirds. Biology Letters. https://doi.org/10.1098/rsbl. 2017.0406.

Vanschoenwinkel, B., S. Gielen, M. Seaman \& L. Brendonck, 2008a. Any way the wind blows - frequent wind dispersal drives species sorting in ephemeral aquatic communities. Oikos 117: 125-134.

Vanschoenwinkel, B., S. Gielen, H. Vandewaerde, M. Seaman \& L. Brendonck, 2008b. Relative importance of different dispersal vectors for small aquatic invertebrates in a rock pool metacommunity. Ecography 31: 567-577.

Vanschoenwinkel, B., A. Waterkeyn, T. I. M. Vandecaetsbeek, O. Pineau, P. Grillas \& L. U. C. Brendock, 2008c. Dispersal of freshwater invertebrates by large terrestrial mammals: a case study with wild boar (Sus scrofa) in Mediterranean wetlands. Freshwater Biology 53(11): 2264-2273.

Vanschoenwinkel, B., A. Hulsmans, E. de Roeck, C. de Vries, M. Seaman \& L. Brendonck, 2009. Community structure in temporary freshwater pools: disentangling the effects of habitat size and hydroregime. Freshwater Biology 54: 1487-1500.

Vopel, K. \& G. Arlt, 1995. The fauna of floating cyanobacterial mats in the oligohaline eulittoral zone off Hiddensee (South-west Coast of the Baltic Sea). Marine Ecology 16: 217-231.

Wallace, H. R., 1958. Movement of eelworm. Annals of Applied Biology 46: 74-85.

Wallace, H. R., 1968. The dynamics of nematode movement. Annual Review of Phytopathology 6: 91-114.

Wallace, H. R. \& C. C. Doncaster, 1964. A comparative study of the movement of some microphagous, plant-parasitic and animal-parasitic nematodes. Parasitology 54: 313-326.

Walters, K. \& S. S. Bell, 1986. Diel patterns of active vertical migration in seagrass meiofauna. Marine Ecology Progress Series 34(1-2): 95-103.

Watanabe, M., 2006. Anhydrobiosis in invertebrates. Applied Entomology and Zoology 41: 15-31.

Waterkeyn, A., O. Pineau, P. Grillas \& L. Brendonck, 2010a. Invertebrate dispersal by aquatic mammals: a case study with nutria Myocastor coypus (Rodentia, Mammalia) in Southern France. Hydrobiologia 654: 267-271.
Waterkeyn, A., B. Vanschoenwinkel, S. Elsen, M. Anton-Pardo, P. Grillas \& L. Brendonck, 2010b. Unintentional dispersal of aquatic invertebrates via footwear and motor vehicles in a Mediterranean wetland area. Aquatic Conservation: Marine and Freshwater Ecosystems 20: 580-587.

Weber, S. \& W. Traunspurger, 2015. The effects of predation by juvenile fish on the meiobenthic community structure in a natural pond. Freshwater Biology 60: 2392-2409.

Weber, S. \& W. Traunspurger, 2016. Effects of juvenile fish predation (Cyprinus carpio L.) on the composition and diversity of free-living freshwater nematode assemblages. Nematology 18: 39-52.

Weber, S. \& W. Traunspurger, 2017. Invasive red swamp crayfish (Procambarus clarkii) and native noble crayfish (Astacus astacus) similarly reduce oligochaetes, epipelic algae, and meiofauna biomass: a microcosm study. Freshwater Science 36: 103-112.

Widborn, B., 1983. Colonization of azoic sediment by sublittoral meiofauna in Gullmar Fjord - Swedish West Coast. Oceanologica Acta 213: 213-217.

Wieser, W., 1959. The effect of grain size on the distribution of small invertebrates inhabiting the Beaches of Puget Sound. Limnology and Oceanography 4: 181-194.

Williams, D. D., 1977. Movements of benthos during the recolonization of temporary streams. Oikos 29: 306-312.

Williams, D. D., 1980. Invertebrate drift lost to the sea during low flow conditions in a small coastal stream in Western Canada. Hydrobiologia 75: 251-254.

Williams, D. D. \& H. B. N. Hynes, 1976. The recolonization mechanisms of stream benthos. Oikos 27: 265.

Wyatt, T. \& J. T. Carlton, 2002. Phytoplankton introductions in European coastal waters: why are so few invasions reported? CIESM Workshop Monographs 20: 41-46.

Yen, J., 1988. Directionality and swimming speeds in predatorprey and male-female interactions of Euchaeta rimana, a subtropical marine copepod. Bulletin of Marine Science 43: 395-403.

Zhou, X., L. Cai \& S. Fu, 2015. Comparison of meiofaunal abundance in two mangrove wetlands in Tong'an Bay, Xiamen, China. Journal of Ocean University of China 14: 816-822.

Zotz, G. \& W. Traunspurger, 2016. What's in the tank? Nematodes and other major components of the meiofauna of bromeliad phytotelms in Lowland Panama. BMC Ecology 16: 9.

Zullini, A., 2014. Is a biogeography of freshwater nematodes possible? Nematology 16: 1-8.

Publisher's Note Springer Nature remains neutral with regard to jurisdictional claims in published maps and institutional affiliations. 